Article

\title{
Characteristics of Sub-Aerially Emplaced Pyroclasts in the Surtsey Eruption Deposits: Implications for Diverse Surtseyan Eruptive Styles
}

\author{
Andrea Verolino ${ }^{1}\left(\mathbb{D}\right.$, James D. L. White ${ }^{2, * \mathbb{D}}$, Rachael J. M. Baxter ${ }^{2,3}$, C. Ian Schipper ${ }^{4}$ and Thor Thordarson ${ }^{5}$ \\ 1 Earth Observatory of Singapore, Nanyang Technological University, 50 Nanyang Ave, \\ Singapore 639798, Singapore; andrea.verolino@ntu.edu.sg \\ 2 Geology Department, University of Otago, P.O. Box 56, Dunedin 9054, New Zealand; \\ Rachel.baxter@otago.ac.nz \\ 3 Department of Earth Sciences, University of Cambridge, Downing Street, Cambridge CB2 3EQ, UK \\ 4 School of Geography, Environment and Earth Sciences, Victoria University of Wellington, P.O. Box 600, \\ Wellington 6140, New Zealand; ian.schipper@vuw.ac.nz \\ 5 Institute of Earth Sciences, University of Iceland, Askja, Sturlugata 7, 101 Reykjavík, Iceland; torvth@hi.is \\ * Correspondence: james.white@otago.ac.nz
}

Citation: Verolino, A.; White, J.D.L.; Baxter, R.J.M.; Schipper, C.I.;

Thordarson, T. Characteristics of Sub-Aerially Emplaced Pyroclasts in the Surtsey Eruption Deposits: Implications for Diverse Surtseyan Eruptive Styles. Geosciences 2022, 12, 79. https://doi.org/10.3390/ geosciences 12020079

Academic Editors: Riccardo De Ritis, Salvatore Passaro, Alessandra Pensa and Jesus Martinez-Frias

Received: 1 December 2021

Accepted: 29 January 2022

Published: 8 February 2022

Publisher's Note: MDPI stays neutral with regard to jurisdictional claims in published maps and institutional affiliations.

Copyright: (C) 2022 by the authors. Licensee MDPI, Basel, Switzerland. This article is an open access article distributed under the terms and conditions of the Creative Commons Attribution (CC BY) license (https:// creativecommons.org/licenses/by/ $4.0 /)$.

\begin{abstract}
The 1963-1967 shallow-to-emergent eruption in Iceland's Vestmannaeyjar earned a place in the history of volcanology by creating the island of Surtsey while under close observation of volcanologist Sigurdur Thorarinsson (Sigurður Pórarinsson in Icelandic). This is an example of what is now called Surtseyan volcanism, and it included explosive and effusive phases from multiple vents that formed the island of Surtsey itself, as well as one fully subaqueous pyroclastic edifice and two additional, but ephemeral, islands. Sigurdur Thorarinsson identified tephra jetting and continuous uprush as characteristic types of subaerial explosive activity of Surtseyan volcanism. Subaerial cone-forming deposits of Surtseyan volcanism are typically poorly sorted, with fine-grained beds rich in sideromelane ash fragments, punctuated by larger, ubiquitously composite bombs, whereas deposits sampled by coring deep into the submarine edifice include fines-poor horizons dominated by vesicular coarse sideromelane ash. Here, we present new textural data and highlight the diversity of pyroclasts and microtextures from Surtsey (Surtur I and Surtur II) and its satellite vents (Surtla, Syrtlingur and Jolnir), in the context of Surtseyan volcanism. We used several sample sets. Some were collected during the 3.5-year long eruption and were conserved in the Icelandic Natural History Museum, including one sample from the core drilled into Surtsey in 1979. Other samples were collected during more recent field campaigns on Surtsey Island. In closing, we discuss the implications of this diversity for the range of activity and products produced by Surtsey.
\end{abstract}

Keywords: Surtsey; Surtseyan volcanism; phreatomagmatic eruptions; pyroclasts; sideromelane; tachylite; blocky; vesicular

\section{Introduction}

\subsection{The Eruptions of Surtsey and Surtseyan Volcanism}

The eruption of Surtsey is inferred to have begun from a short submarine fissure at $130 \mathrm{~m}$ below sea level in November 1963. It continued until June 1967, forming other vents (Surtla, Syrtlingur, and Jolnir) along a SW-NE oriented alignment [1]. The eruption as a whole created at least two ephemeral and one longer-lived island in the North Atlantic, SW of the main Iceland landmass (Figure 1a,c). The eruption was well documented by Sigurdur Thorarinsson in particular (see [2,3] who reported, along with other members of the Surtsey Research Society, through the Surtsey Research Reports-https: / surtsey. is / utgafa-surtseyjarfelagsins / access on 20 January 2022 - and other venues [2-6]). The earliest international publication [4] was produced during the first eruptive phase. Other 
authors revisited and summarized the eruption's progression from its shallow submarine beginnings, emergent phreatomagmatic phases, to its lava flows and dry Hawaiian and fire fountaining explosive phases [3,4,7-19]. A wide spectrum of subaerial eruption styles was observed during Surtsey's emergence, including several effusive/mild-explosive dry phases from 1964 to 1967, which produced lava ponds, lava fountains and tube-fed lava flows [19]. "Continuous uprush" plumes, and tephra jetting ("cock's tail" or "cypressoid" jets; Figure 1b; [3]) are, however, the styles that most strongly differentiate Surtseyan eruptions from dry explosive mafic eruptions [8,11], where there is no (or negligible) interaction between magma and external water. Surtsey's subaerial explosive eruptive phases deposited poorly sorted tephra to form two tuff cones, Surtur I and Surtur II. The Surtsey eruption deposited locally and is inferred to have produced a greater proportion of ash than the equivalent dry / magmatic mafic eruption; this was identified as a characteristic feature of phreatomagmatic deposits [8].
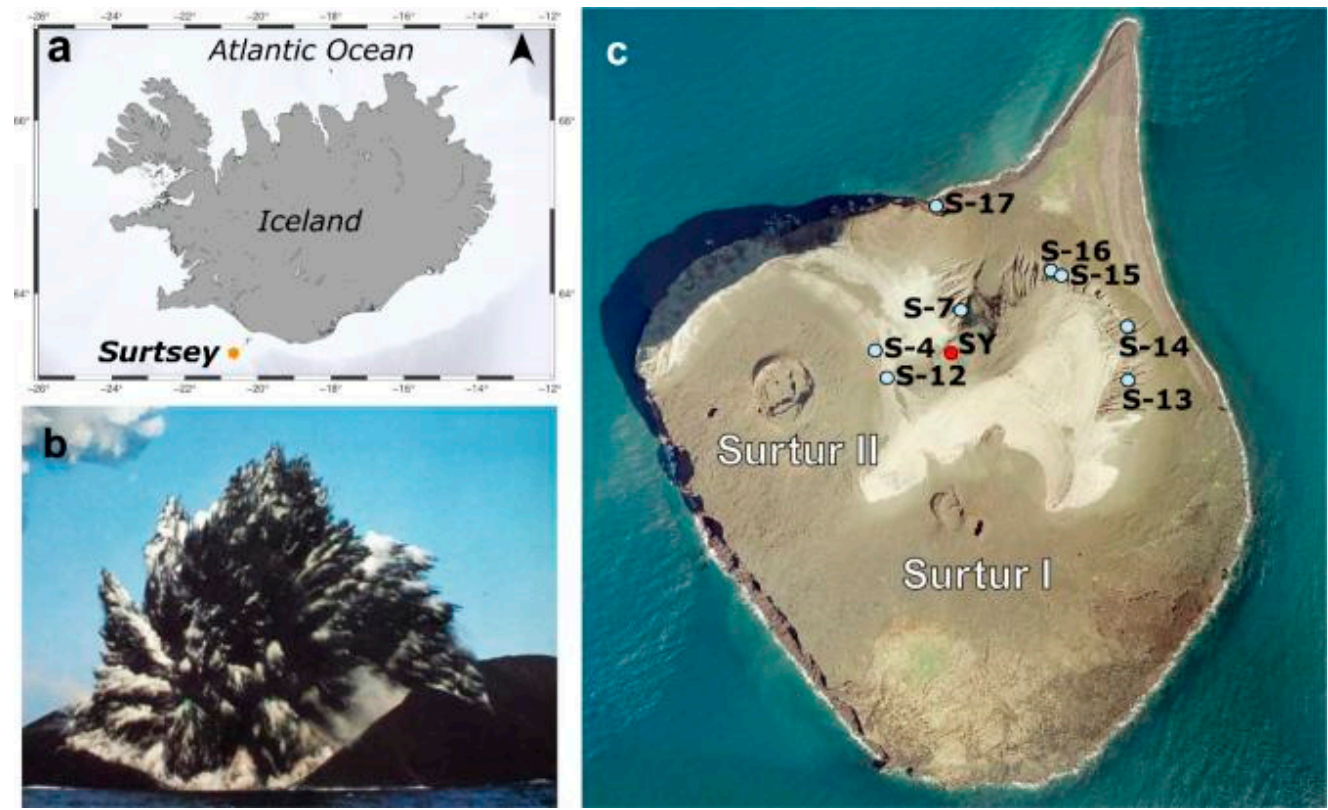

Figure 1. Location: (a) position of the island of Surtsey, SSW of Iceland's mainland in the North Atlantic; (b) Surtsey in eruption (photo by Sverrir Einarsson); (c) orthophoto of Surtsey, taken in 2012 (courtesy of Loftmyndir ehf), with sample locations provided for the two sample sets collected on the island in 2014 (S samples, light blue dots) and 1991 (SY samples, red dot).

Only years before Surtsey's eruption, the Capelhinos volcano (Azores, Atlantic Ocean) in 1957 was formed by a shallow marine, explosive eruption of basalt with vapor-rich plumes and cool lateral currents. Aspects of the eruption were reported and later analysed $[20,21]$, but the quality and duration of eruption observations were modest. In 1963-1967, Surtsey erupted, and became the "Rosetta Stone" of Surtseyan volcanism on the basis of Thorarinsson's outstanding and sustained documentation of the long-lived eruption. Many authors, attracted by unusual or unique features of the Surtsey eruption, draw on information from Surtsey to help understand eruptions of other volcanoes with similar products. Most studies on Surtseyan volcanism have focused on phenomena observed at the surface (e.g., [3,11,21,22], although some authors have focused attention on the processes taking place underwater (e.g., [14,23-27]), while others have approached the eruptive phenomena experimentally (e.g., [28-32]). Surtsey itself has been the object of several recent geological studies (e.g., $[16,17])$, including geochemical characterization of the products [18,33,34], analysis of the island's morphological evolution in the last 50 years [35], analysis of the eruption's dynamics focused on processes of mingling between magma and a water-saturated slurry within or around the vent [36] and re-analysis of historical seismic data [37]. Coring of the island volcano in 1979 by the Icelandic Museum of Natural History 
and United States Geological Survey, and in 2015 by the International Continental Drilling Project (ICDP) [1,38], has provided an unparalleled opportunity to investigate, in three dimensions, both original deposit features and the temporal progression of alteration in the island's interior [38-40].

The rich record of direct observations of the eruption provides exceptional context for interpretation of its subaerial deposits and particularly of features inferred to result from, and thus reflect, near-surface interactions of magma with seawater. This magma acquired certain textural features during ascent, to which were added features developed during interaction with the water column above the subaqueous vent as it sent tephra into the air to be deposited subaerially. Such late-stage influences are typically captured in textural details of pyroclasts (e.g., [41,42]).

With the present work, we aim to highlight the range of pyroclast textures from Surtsey and its satellite vents. Surtseyan pyroclasts are commonly characterized as blocky (in the ash fraction), cracked, low-porosity sideromelane particles. Such particles are abundant and important in deposits of the Surtsey eruption, but there is additional information about eruptive processes in the smaller but not insignificant population of other pyroclasts produced during explosive phases, particularly in the lapilli population. We highlight these differences using a number of sample collections, analysed with a variety of techniques (Table 1), with support from published data of 3D porosity and permeability [32]. Not addressed in this paper are the products formed during the effusive phase with emplacement of lava flows (intermittent between 1964 and 1967). We do, however, for comparison with the phreatomagmatic products, present analyses of some ash particles formed during mildly explosive lava fountaining from the then subaerial vent on Surtsey Island in August 1966.

Table 1. List of samples used for this study.

\begin{tabular}{|c|c|c|c|c|c|c|}
\hline Sample Name & Size Fraction & Eruption Date & Collected By & Sampling Location & Analysis & Deposit Description \\
\hline \multicolumn{7}{|c|}{1991 and 2014 field campaigns on Surtsey } \\
\hline S-4,6 & \multirow{4}{*}{ Ash/Lapilli } & Feb '64 & $\begin{array}{l}\text { JDL White, CI } \\
\text { Schipper }\end{array}$ & Surtur II flank & $1,2,3$ & See text (Section 2.1) \\
\hline S-17,17 & & Feb ${ }^{\prime} 64$ & $\begin{array}{l}\text { JDL White, CI } \\
\text { Schipper }\end{array}$ & Surtur I flank & $1,2,3$ & See text (Section 2.1) \\
\hline $\mathrm{S}-7,3$ & & Feb '64 & $\begin{array}{l}\text { JDL White, CI } \\
\text { Schipper }\end{array}$ & Surtur I flank & $1,2,3$ & See text (Section 2.1) \\
\hline S-16,16 & & Feb ${ }^{\prime} 64$ & $\begin{array}{l}\text { JDL White, CI } \\
\text { Schipper }\end{array}$ & Surtur I flank & $1,2,3$ & See text (Section 2.1) \\
\hline S-15,15 & \multirow[b]{5}{*}{ Ash/Lapilli } & Feb '64 & $\begin{array}{l}\text { JDL White, CI } \\
\text { Schipper }\end{array}$ & Surtur I flank & $1,2,3$ & See text (Section 2.1) \\
\hline S-14 & & Feb ${ }^{\prime} 64$ & $\begin{array}{l}\text { JDL White, CI } \\
\text { Schipper }\end{array}$ & Surtur I flank & $1,2,3$ & See text (Section 2.1) \\
\hline S-13,13 & & Feb '64 & $\begin{array}{l}\text { JDL White, CI } \\
\text { Schipper }\end{array}$ & Surtur I flank & $1,2,3$ & See text (Section 2.1) \\
\hline S-12,13 & & Feb '64 & $\begin{array}{l}\text { JDL White, CI } \\
\text { Schipper }\end{array}$ & Surtur II flank & $1,2,3$ & See text (Section 2.1) \\
\hline SY 01 to SY 20 & & $\begin{array}{l}\text { Feb '64 } \\
\text { Collectio }\end{array}$ & $\begin{array}{l}\text { T Thordarson } \\
\text { the Icelandic Nat }\end{array}$ & $\begin{array}{l}\text { Surtur I flank } \\
\text { l History Museum }\end{array}$ & 4,6 & See text (Section 2.1) \\
\hline Sur1-801 & $\begin{array}{c}\text { Ash } \\
\text { (Surtur I) }\end{array}$ & 17 Nov $^{\prime} 63$ & G Kjartansson & $\begin{array}{l}\text { Collected from fallout } \\
\text { onboard v/s Odni, } 3 \\
\text { km from Surtsey }\end{array}$ & 4,5 & \multirow{2}{*}{$\begin{array}{c}\text { Greyish tephra, } \\
\text { poorly sorted, with } \\
\text { outsized }(\sim 1 \mathrm{~cm}) \text { flaky } \\
\text { particle. } \\
\text { Well sorted tephra, } \\
\text { lacking much } \\
\text { ultrafine material. } \\
\text { Larger grains have } \\
\text { ropy, achnelithic-like } \\
\text { surfaces. }\end{array}$} \\
\hline Sur1-9809 & & $15 \operatorname{Nov}^{\prime} 63$ & S Thorarinsson & $\begin{array}{l}\text { Collected from fallout } \\
\text { onboard v/s Albert }\end{array}$ & 4,5 & \\
\hline Sur1-9810 & & $15 \operatorname{Nov}^{\prime} 63$ & S Thorarinsson & $\begin{array}{l}\text { Collected from fallout } \\
\text { onboard v/s Albert } \\
\text { Collected during }\end{array}$ & 4,5 & $?$ \\
\hline Sur1-9811 & & $16 \operatorname{Nov}^{\prime} 63$ & S Thorarinsson & $\begin{array}{l}\text { fallout onboard } \\
\text { fishing vessel } \\
\text { Haraldur }\end{array}$ & 4,5 & $\begin{array}{l}\text { Graded greyish } \\
\text { tephra }\end{array}$ \\
\hline
\end{tabular}


Table 1. Cont.

\begin{tabular}{|c|c|c|c|c|c|c|}
\hline Sample Name & Size Fraction & Eruption Date & Collected By & Sampling Location & Analysis & Deposit Description \\
\hline Sur1-9813 & & $23 \operatorname{Nov}^{\prime} 63$ & S Thorarinsson & $\begin{array}{c}\text { Collected from fallout } \\
\text { onboard } \mathrm{v} / \mathrm{s} \text { Thor }\end{array}$ & 4,5 & $\begin{array}{c}\text { Greyish fine-grained } \\
\text { tephra }\end{array}$ \\
\hline Sur1-9816 & & $1 \mathrm{Dec}^{\prime} 63$ & S Thorarinsson & $\begin{array}{c}\text { Collected from fallout } \\
\text { onboard v/s Ódinn at } \\
7 \text { pm }\end{array}$ & 3 & $\begin{array}{l}\text { Greyish fine-grained } \\
\text { tephra, with ultrafine } \\
\text { component. }\end{array}$ \\
\hline Syrt-9833 & & Jun-Jul '65 & $?$ & $\begin{array}{c}\text { Syrtlingur tephra } \\
\text { collected atop Surtur } \\
\text { II lavas }\end{array}$ & 4,5 & $\begin{array}{l}\text { Fine-coarse ash with } \\
\text { small flakes }<4 \mathrm{~mm} \\
\text { wide. }\end{array}$ \\
\hline Syrt-11220 & & Jul '65 & P. Helgasyni & $\begin{array}{l}\text { Syrtlingur tephra } \\
\text { collected on } \\
\text { Syrtlingur }\end{array}$ & 3 & $\begin{array}{l}\text { Well sorted black } \\
\text { medium ash. } \\
\text { Completely non } \\
\text { vesicular- } \\
\text { sideromelane and } \\
\text { crystals. }\end{array}$ \\
\hline Jol-9846 & & 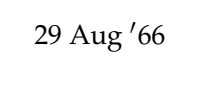 & SP Jakobsson & $\begin{array}{c}\text { Jólnir tephra collected } \\
\text { on N Surtsey } \\
\text { collected close to }\end{array}$ & 3 & $\begin{array}{c}\text { Tephra. Fine to coarse } \\
\text { dusty ash. }\end{array}$ \\
\hline SLF-4680 & & 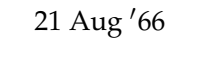 & $?$ & $\begin{array}{l}\text { crater mouth of } \\
\text { Surtur II }\end{array}$ & 4,5 & Pele's hair and tears \\
\hline SDC79-176.0 & Ash & 8-14 Nov' 63 & SP Jakobsson & $\begin{array}{c}\text { Base of the } 1979 \\
\text { Surtsey Drill Core } \\
\text { (176 m deep, } \sim 120 \\
\text { m.b.s.l.) }\end{array}$ & 3 & $\begin{array}{l}\text { Unconsolidated and } \\
\text { unaltered tephra rich } \\
\text { in vesicular grains. }\end{array}$ \\
\hline
\end{tabular}

1, granulometry; 2, componentry; 3, optical microscopy; 4, BSE, SEI imaging; 5, 2D porosity; 6, 3D porosity, permeability (data from [32]). S and SY, Surtsey island; SDC79, Surtsey drill core 1979; Syrt, Syrtlingur; Jol, Jolnir; Sur1, Surtur I; SLF, Surtsey lava fountaining. Note that SLF-4680 represents the only sample analysed here from the dry subaerial magmatic phase of Surtsey.

\subsection{Pyroclast Microtextures}

The quantification of vesicle and crystal microtextures in pyroclasts [43] can be an effective tool for assessing magma ascent rates, as well as exsolution and outgassing processes [44]. These microtextures, preserved in single pyroclasts, are best interpreted in the context of the deposits from which they are extracted. The distance from the vent affects deposit thickness and average grainsize in fall deposits; sorting is a function of transport and depositional process as well as emitted particle populations; near the vent, large clasts and quickly accumulated deposits may remain hot after deposition, thermally overprinting textures of their pyroclasts [45]. Microtextures of pyroclasts formed in dry subaerial explosive eruptions have heterogeneities resulting from waxing or waning eruption intensity [46], evolving vent and/or conduit geometries [47], plus clast modification during transport [48]. To analyse particle-forming processes, samples retaining the signatures of those processes must be carefully selected. For Surtseyan activity, we make a primary distinction between the products formed during the subaqueous edifice-building phase versus those from subsequent subaerial eruptive phases.

\subsubsection{Surtseyan Edifice-building Subaqueous Deposits}

Subaqueously erupted pyroclasts travel through water, which changes dispersal but may more effectively preserve syn-fragmentation textures in ash by rapid quenching [45]. Previous authors $[1,49]$ described cores extracted from the subaqueous edifice of Surtsey (note that $[13,50]$ inferred that only slumped subaerial deposits were penetrated). A bomb from Surtla was described [51] and geochemically analysed [18]. Lacustrine volcanoes of the western US erupted into extensive lakes formed during Pleistocene glacial and interglacial times, and they provide exceptional views of proximal to near-medial subaqueously formed deposits $[14,26,52]$. The cited works assessed the architecture and depositional features of subaqueous deposits of Surtseyan eruptions, the deposits' particle characteristics including grain size, morphology and porosity, and their distribution within the lakes into which the volcanoes erupted. 


\subsubsection{Surtseyan Subaerial Deposits}

Surtseyan eruptions are subject to all sources of heterogeneity inherent to both subaerial and subaqueous eruptions, because once an island forms, surface water can be fully, partially, or intermittently blocked from entering the eruptive vent $[3,11,13]$. Several recent studies have quantitatively addressed these issues using pyroclasts from shallow subaqueous eruptions of Miyakejima, Japan [53], Capelas tuff cone, Azores [54], and Ilchulbong tuff coney microlitedmassc glass yan ata the presence of blocky sideromelanets II with locations and lithological descritpions. (S sampl, South Korea [55]. These studies build on an earlier work [8] that presents important observations and provides an influential list of deposit features characteristic of Surtseyan cone deposits, particularly emphasizing their finer grainsize and paucity of achneliths compared to deposits from dry eruptions of similar intensity. Much subsequent work has confirmed and embraced these characteristic features, but only rarely has emphasis been placed on the wider diversity of grain shapes and microtextures present in Surtsey's deposits [36] or those of other Surtseyan eruptions $[27,52,56]$. Here, we provide qualitative and quantitative information about selected pyroclasts of "the Surtsey eruption" from both the island of Surtsey and its satellite vents. We highlight the textural diversity of pyroclasts and discuss both processes that produced them and implications of their diversity for interpreting deposits from other potentially Surtseyan eruptions.

\section{Materials and Methods}

\subsection{Samples}

We examined samples from different eruptive phases (only one sample from the dry subaerial magmatic phase) from Surtsey and its satellite vents (Table 1). Most samples representing activity on Surtsey itself were collected from the outer northern cone flank of the "Surtur I" vent, with two of them (samples S-4 and S-12, Figure 2) from the cone flank of "Surtur II" (Figure 1c). Lapilli (SY samples) are from the NW flank of Surtur I (Figure 1c). Common features across these deposits include inversely graded layers $(\sim 100-150 \mathrm{~cm}$ thick), from fine-moderate lapilli-dominated base to moderate-coarse lapilli-dominated at the top, with moderate proportions (20-40\%) of ash ( $<2 \mathrm{~mm} \mathrm{[57])} \mathrm{throughout.} \mathrm{Internal}$ structures of these layers include lenses of well-sorted lapilli separated by layers of ash. These 50-150 cm long, 2-10 cm thick lenses are fine-grained at the margins, coarsening towards the centre. All of these samples (S and SY sample sets, Table 1) are inferred from field relationships to have erupted from "Surtur II" in February 1964 and were collected during two field campaigns in 1991 (SY samples) and 2015 (S samples), respectively. We also analysed one sample from the subaqueous edifice-building stage of Surtsey, which belongs to the sample collection of the 1979 drill core project, conducted by the Icelandic Natural History Museum and the US Geological Survey. The sample analysed was extracted from the deepest portion of the core (176 m deep, equivalent to $120 \mathrm{~m}$ below sea level at the time of eruption), which was unconsolidated and unaltered in 1979 (and remains so). Other samples from the collection of the Icelandic Natural History Museum were also analysed, and include samples from Surtsey's ephemeral vents Syrtlingur and Jólnir (erupted in 1965 and 1966 respectively), samples erupted from Surtur I in November 1963, and one sample from deposits of the August 1966 subaerial magmatic lava fountaining phase of Surtur I. 

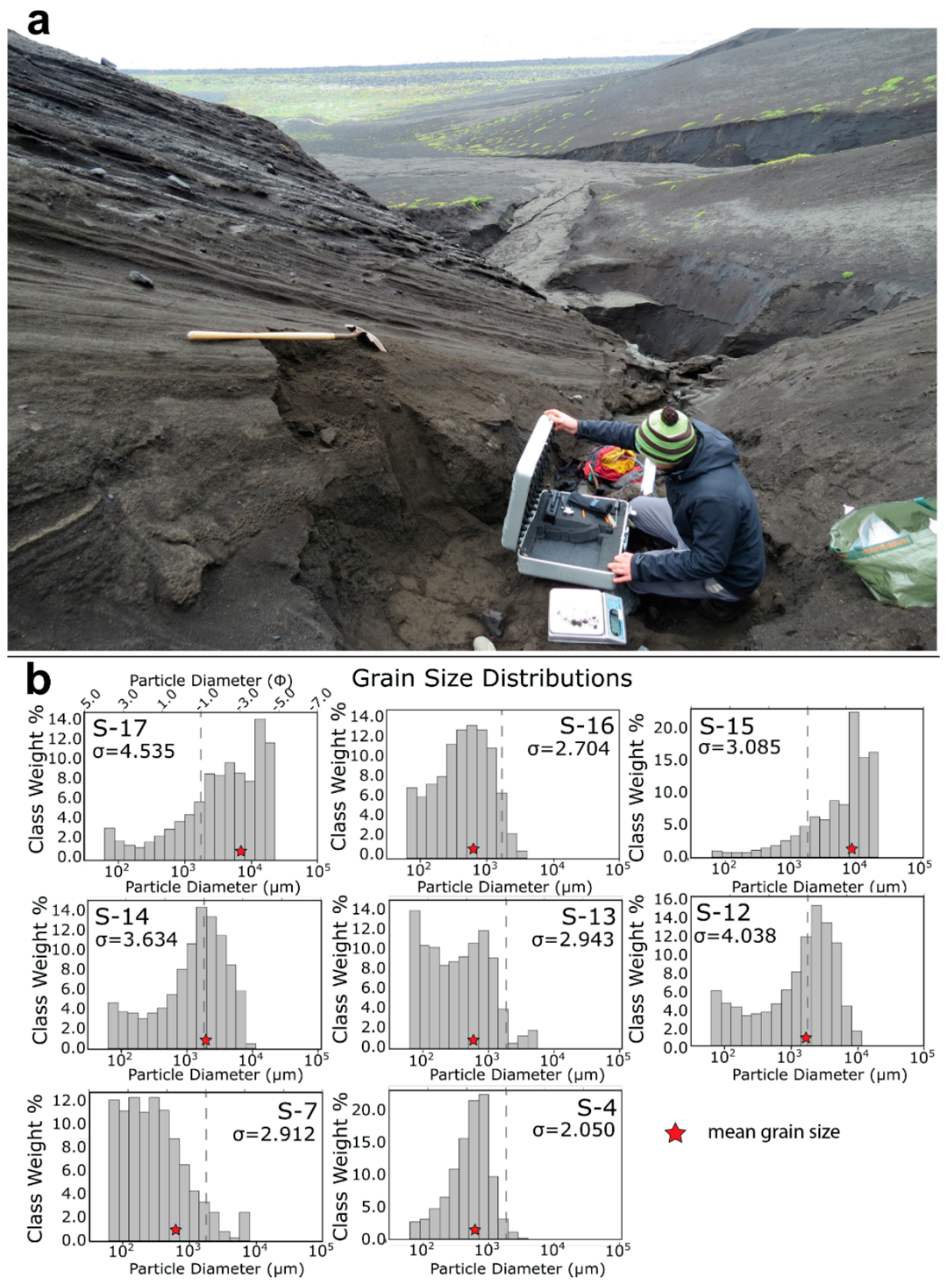

Figure 2. (a) Field photo showing the outcrop where the lapilli analysed for this study (SY sample set) were sampled; and (b) grain size distributions for the samples (S sample set) collected in 2014 (see Figure 1 for exact sample locations). The dashed lines represent the different fields for ash (left side) and lapilli (right side), following the classification of [57].

\subsection{Analytical Methods}

Grain size analyses (Figure 2) at the University of Otago involved dry hand sieving, between $-4 \Phi(16 \mathrm{~mm})$ and $4 \Phi(0.063 \mathrm{~mm})$ at intervals of $0.5 \Phi$, with results processed using Gradistat ${ }^{\circledR}$ v4.0 [58]. For componentry, 100 grains from each of three different half $\Phi$ size fractions, $-2 \Phi(4 \mathrm{~mm}), 0 \Phi(1 \mathrm{~mm}), 2 \Phi(0.25 \mathrm{~mm})$, were counted and characterized, totalling around 300 grains / sample. Observed groundmass textures in the tephra grains are (i) "sideromelane", i.e., hypohyaline basaltic glass, i.e., nearly microlite-free; (ii) "tachylite", i.e., basalt with microlite-dominated groundmass; (iii) "transitional", referring to grains with domains of both (i) and (ii). Tachylite is optically opaque in standard thin sections because a dense population of sub-microscopic crystals chaotically refracts light rather than passing it through single crystals in a standard $0.3 \mathrm{~mm}$ thin section. 
We used a Phoenix Nanotom 180 X-ray computed microtomograph $(\mu-c T)$ at l' Université d' Orléans to examine internal textures of lapilli in a qualitative and quantitative way in three dimensions. The porosities and permeabilities calculated from these data and presented by [32] are further discussed in this paper. Totals of 2000-2300 scans of each lapillus were collected during $360^{\circ}$ rotation, using a tungsten filament and molybdenum target. Operating voltages were in the range 80 to $100 \mathrm{keV}$, with currents of 50-90 nA. Voxel edge lengths for the analysed lapilli ranged from 1.7 to $3.4 \mu \mathrm{m}$, which captured even the smaller vesicle populations (as assessed by SEM-see below). Raw scans were reconstructed into stacks of greyscale images with an offline PC microcluster running Phoenix datos I x v. 2.2 reconstruction software. After lapilli were scanned, we mounted them in epoxy briquettes, and ground and polished interior surfaces for bubble wall and groundmass examination on the JEOL WINSET JSM 6400 scanning electron microscope (SEM) at l' Université d' Orléans.

Lapilli vesicle textures were quantified for representative elementary volumes (REV), usually $750 \mathrm{px}^{3}$, and always $\geq 500 \mathrm{px}^{3}$ of each $\mu$-cT scan. Multiple sub-volumes capturing the range of groundmass and vesicle heterogeneity in natural lapilli were isolated and analysed separately, as appropriate for each clast. Vesicles were measured using the 3D object counter plugin for Image J, after thresholding greyscale sub-volumes to isolate void space from glass and phenocrysts. SEM imaging does not reveal the optical opacity of groundmass, so the term tachylite is applied to "microlite-rich" groundmass, and sideromelane to microlite-poor groundmass [59].

In cases where clasts contain distinct textural domains, we divided scans into multiple representative subvolumes for quantitative analysis. In cases where the scanned clast contains a discrete (captured) particle, we selected REVs to exclude the captured clast, such that textural parameters are calculated for the bulk magma in which the particle was captured during hot-state recycling. In cases where the captured material was ash, now enclosed in vesicles, we isolated and segmented multiple REVs where possible, to capture both ash-free and ash-bearing subvolumes.

The quantification of textural parameters is dependent on scan resolution and selection of a representative elementary volume (REV). If resolution is too low to capture the thinnest of bubble walls, calculations will systematically yield higher calculated porosity (a slight effect) and lower bubble number density $\left(\mathrm{N}_{\mathrm{V}}\right)$. No textural parameters were physically measured by, e.g., porosimetry or permeametry, in this study. Instead, we relied on careful characterization of observed textures and a series of tests designed to assess data accuracy. After $\mu$-cT scanning, bubble walls were examined by backscatter electron imaging (BSE). The average thickness of the 10 thinnest bubble walls seen and measured in a BSE image was taken to be a representative cutoff wall thickness $\left(\mathrm{d}_{\min }\right)$. If scan resolution was sufficient to capture $\mathrm{d}_{\min }$, it was considered to accurately capture framework components.

We also mounted ash particles from the 4.0 to $3.0 \Phi$ range $(63-125 \mu \mathrm{m})$, both as polished and unpolished grain mounts. We used backscatter electron imaging (BSE) at l' Université d' Orléans to examine groundmass textures of fine ash on the polished grain mounts, and on a JEOL JXA-8600 Superprobe at the University of Otago to examine morphological features on the unpolished grain mounts (through secondary electron imagery analysis, SEI).

To estimate the 2D porosity of the magma that fragmented to form the fine ash, we analysed BSE images of polished ash grains using ImageJ. Often, grains with no internal vesicles (e.g., porosity $=0$ ) would have an outline shape that belied the presence of vesicles along fracture planes that fragmented the magma. We manually corrected the outline of such grains to include what had been obvious edge vesicles into the porosity calculation.

\section{Results}

\subsection{Grain Size and Componentry Analysis}

The samples considered for granulometry are dominantly poorly sorted, and mean grain size is coarse ash/very coarse ash, with the exception of two samples (S-15 and 
S-17), with mean grain size in the lapilli range (Figure 2). Few samples show unimodal distributions; thus sorting, skewedness and kurtosis values are not fully representative.

For componentry, we considered the size fractions $-2,0$ and $2 \Phi$. Samples in these fractions are dominated by juvenile fragments made primarily of sideromelane (Figure 3). The greatest variations in groundmass texture are observed in the $-2 \Phi$ size fraction. In the $2 \Phi$ size-fraction, there is 3-25\% tachylite or transitional groundmass types (average of $13.4 \%$ ), whereas the $0 \Phi$ fraction has $2-32 \%$ tachylite or transitional groundmass types (average of $14.2 \%$ ). Highly vesicular "golden pumice" fragments occur in the $2 \Phi$ size fraction. Two of the $-2 \Phi$ bins $(S-7,3$ and S-13,13) contained only two fragments each. The remaining $-2 \Phi$ samples have $11-53 \%$ tachylite or transitional groundmass types (average of $34.2 \%$ ). Crystal fragments are common in the 0 and $2 \Phi$ fractions, mostly olivine and some plagioclase. Sample S-4 has the greatest proportion of sideromelane $(96 \%)$, whereas samples S-15, S-14\#1, S-14\#2, S-14\#3 contain 45-70\% sideromelane and concomitantly higher proportions of tachylite clasts (Figure 3). All other samples have $>70 \%$ sideromelane clasts. Lapilli from six out of eleven samples include composite grains (up to $11 \%$ of lapilli). The composite grains are dominated by tachylite groundmass domains.

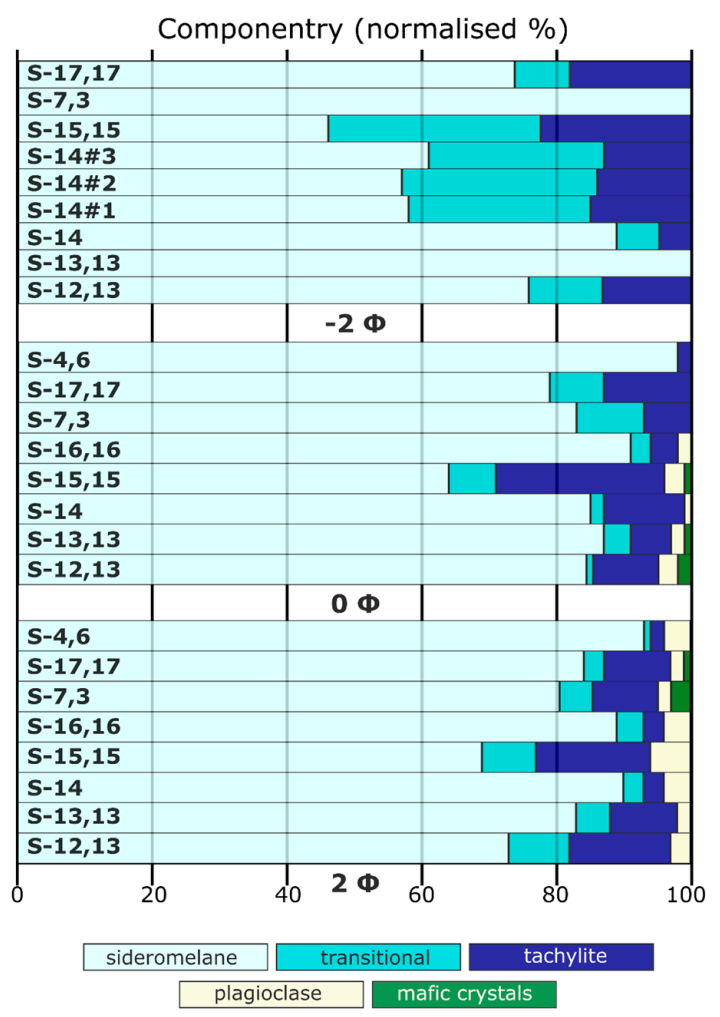

Figure 3. Componentry of the samples collected on Surtsey in 2014 (S samples) within the size fractions $-2,0$ and $2 \Phi$. These samples are inferred to have erupted from Surtur II in February 1964 (see Figure 1 for sample locations and Table 1 for sample details).

\subsection{Textures of Surtseyan Pyroclasts}

\subsubsection{Ash}

Ash grains show a variety of morphologies and textures (Figures 4-6). The outlines of ash particles in the 3.0-3.5 $\Phi$ range commonly reveal the presence of broken vesicles on one or more sides (Figure 6j-1); wholly blocky, dense particles lacking vesicles are also present (Figure 6g-i). Among the blocky particles, stepped features are common (Figure 6h). Another morpho-type is that of more vesicular grains (abundant in the Surtsey surface products and unconsolidated base of the 1979 drill core, Figure 4), with rounded to subrounded vesicles, generally $100 \mu \mathrm{m}$ in diameter or less, and occasionally up to $200 \mu \mathrm{m}$ when elongated (Figure 6d). All these features are identified both through optical, BSE 
and SEI imaging analysis (Figures 4-6). We also identified one moss-like microaggregate particle (Figure 6j, left side).

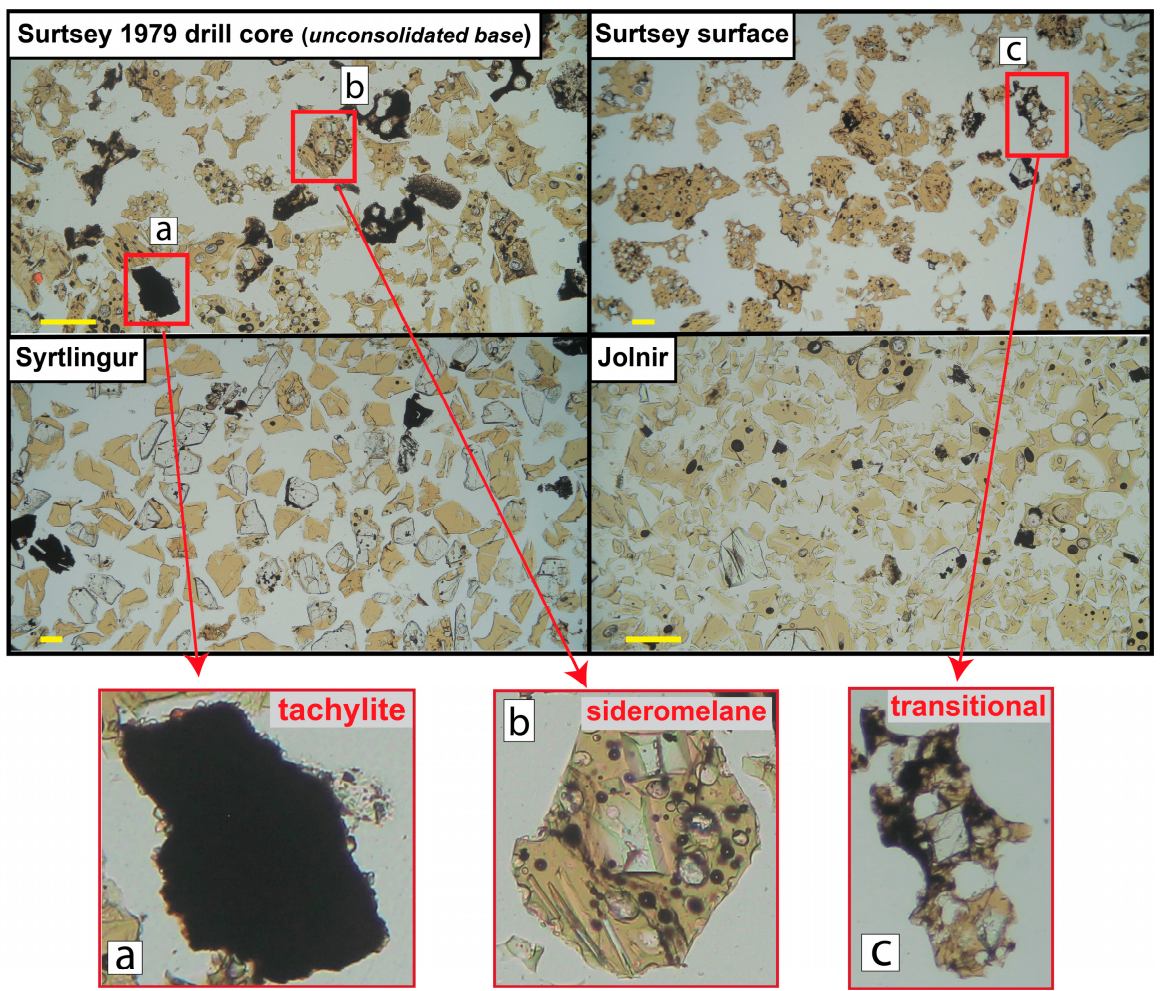

Figure 4. Photomicrographs (plane light) of ash grains from Surtsey and its satellite vents (from the Icelandic Natural History Museum samples collection, Table 1). Note the microtextural variability (a-tachylite, b-sideromelane, $\mathbf{c}$-transitional) across the grains from each location. The yellow bar length is $200 \mu \mathrm{m}$.

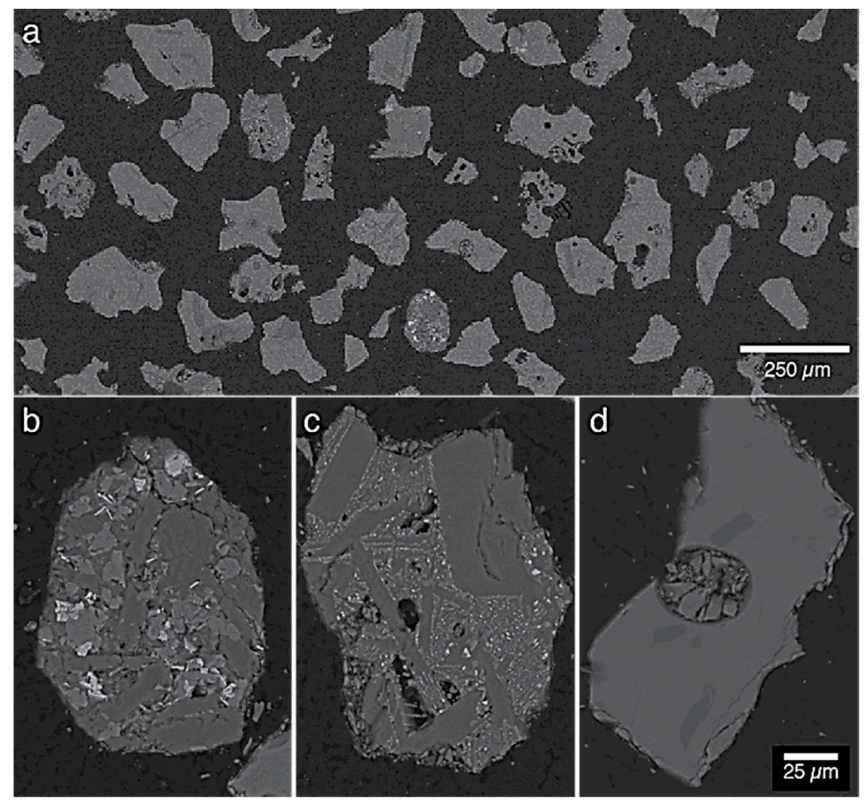

Figure 5. Surtsey ash-grains (from the Icelandic Natural History Museum samples collection, Table 1); shapes and microtextures. (a) Overview of BSE image of fine ash (3.0-3.5 $\Phi$ ) in a polished grain mount. (b-c) Tachylite and (d) sideromelane. 

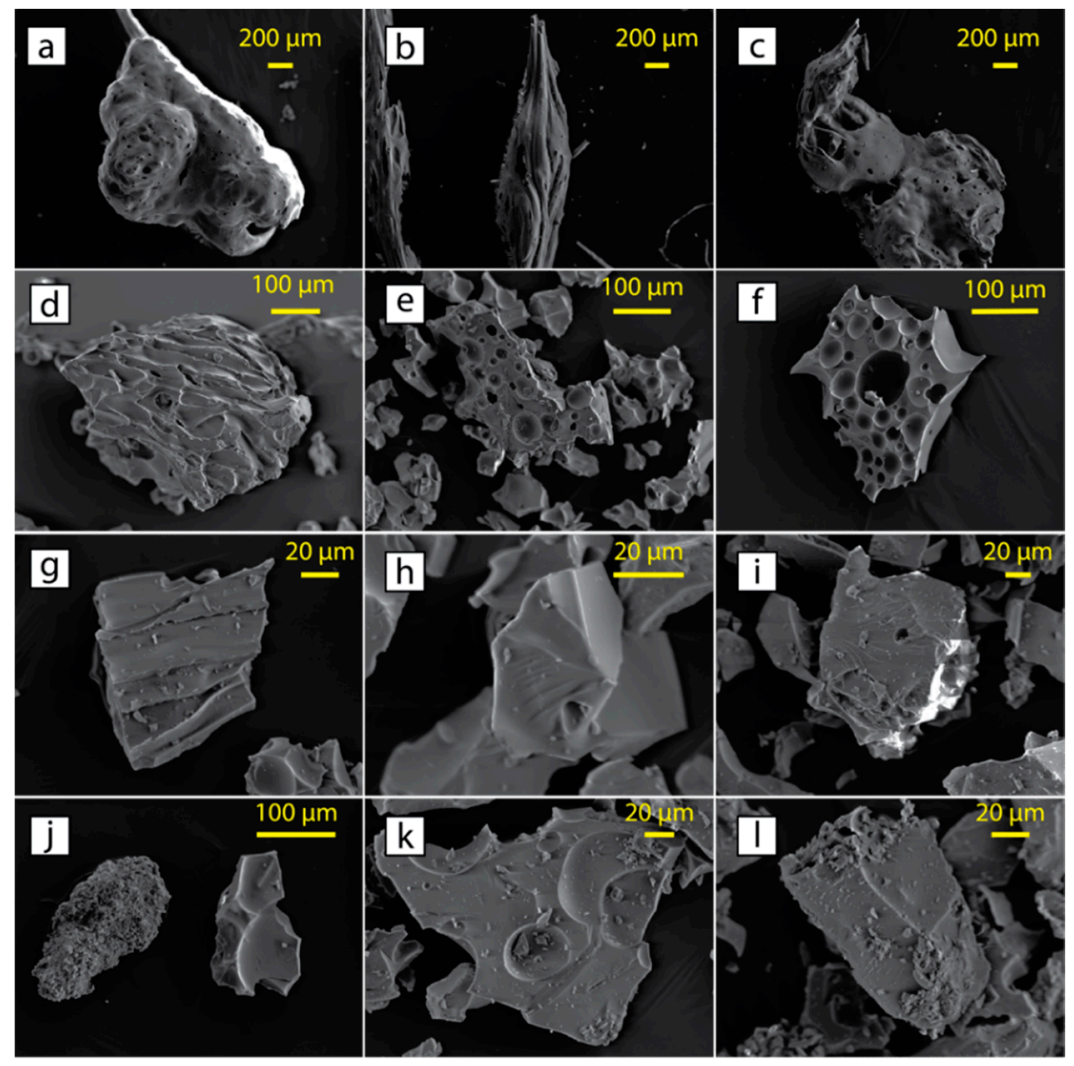

Figure 6. SEI images of fine ash (4.0-3.5 $\Phi$ ) from Surtsey (from the Icelandic Natural History Museum samples collection, Table 1). Note the overall variability of grain shape and porosity at Surtsey, including grains from the subaerial magmatic phase (fluidal grains, $(\mathbf{a}-\mathbf{c})$, and overall Surtseyan activity: vesicular grains $(\mathbf{d}-\mathbf{f})$, blocky grains with stepped features $(\mathbf{g}-\mathbf{i})$, glass shards with broken bubble walls (j-1), and moss-like grains ( $\mathbf{j}$, left side).

The 2D porosity of ash particles $(n=100)$ ranges from $0 \%$ to $35 \%$, but is skewed towards low porosity, with $80 \%$ of analysed particles having porosity $\leq 15 \%$. When viewed as unpolished whole-grain mounts, it can be seen that small microparticles ubiquitously adhere to fracture surfaces in a manner typical of ash produced in phreatomagmatic fragmentation experiments [60]. When viewed as polished grains, optical BSE imaging shows the ash to have three types of groundmass, based on the groundmass crystallinity (Figures 4 and 5). Sideromelane is by far the most common groundmass type in fine ash particles, followed by tachylite and transitional tachylite grains in roughly equal proportions.

Crystal fragments are common in the ash fraction and include plagioclase and olivine. Plagioclase crystals have dimensions from $\sim 30$ to $300 \mu \mathrm{m}$ (long axis); olivine crystals have equant morphologies and range in size from $\sim 100$ to $400 \mu \mathrm{m}$. Olivine crystals can be found either within glass or as individual clasts (Figure 4, Syrtlingur), while plagioclase only presents within glass. Microlites are mostly plagioclase, and their exact size and shape cannot be resolved for the ash fraction through BSE imaging analysis (Figure 5c)

The only subaerial explosive products from Surtsey that we analysed for this study are from the Hawaiian fountaining phase that occurred on Surtur I in August 1966. In particular, we conducted qualitative secondary electron imaging (SEI) analysis of three ash grains (sample SLF-4680) (Table 1), which have rounded to elongated fluidal shapes with smooth surfaces (Figure 6a-c). Porosity was not quantified for these grains.

\subsubsection{Lapilli}

Lapilli analysed for this work show a range of porosity (6-56\%). Lower-porosity grains tend to have partially collapsed vesicles with irregular, tortuous shapes, whereas higherporosity grains tend to have larger sub-spherical vesicles (Figure 7). It is not uncommon 
for a given lapillus to have one or more outsized vesicle $(\geq 1 \mathrm{~mm})$ in its interior; these are randomly located in the clasts and show that relatively large vesicles are sampled even in these ash grains. Across the lapilli analysed, we identified the same three main categories as for the ash fraction: sideromelane, transitional, and tachylite (Figure 7, Table 2). Bubble number density $\left(\mathrm{N}_{\mathrm{v}}\right)$ for these lapilli ranges from $4.05 \times 10^{5}$ to $8.30 \times 10^{6} \mathrm{~cm}^{-3}$ and increases from sideromelane to transitional to tachylitic groundmass-bearing lapilli, whereas porosity decreases. Phenocryst type, size and shape are the same as for the ash particles, and do not appear to vary significantly across the different textures. Microlites are plagioclase with elongate tabular shapes exhibiting skeletal and frequently hopper-shaped textures. Their length (long axis) varies slightly between tachylite domains $(\leq 30 \mu \mathrm{m})$ and transitional domains $(<30 \mu \mathrm{m})$. In places they occur as radial aggregates, particularly in the transitional textures (Figure $7 \mathrm{~b}$, lower panel).
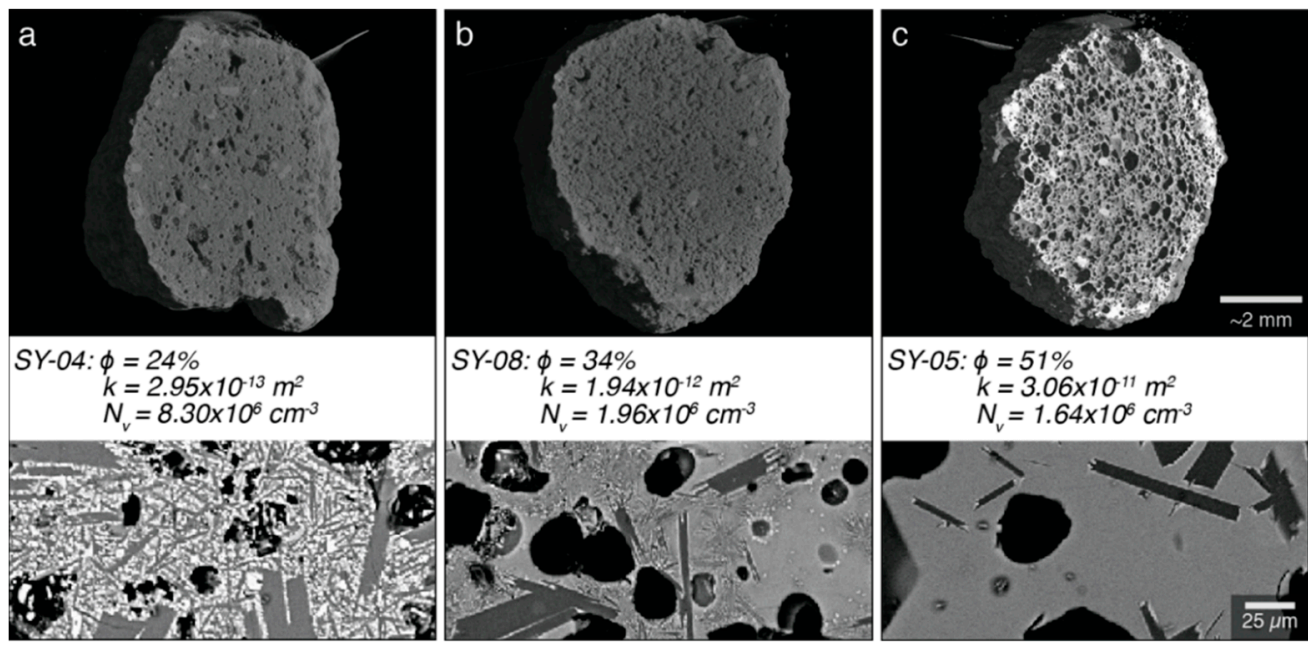

Figure 7. Lapilli textures. Vesicle textures shown as $\mu$-cT reconstructions (top panels), sample names and data reprinted from Table 2 (middle panels), and groundmass textures (bottom panels). Note that from $(\mathbf{a}-\mathbf{c})$, porosity (in this figure $=\phi$ ) and permeability $(\mathrm{k})$ increase, number density $\left(\mathrm{N}_{\mathrm{V}}\right)$ and groundmass crystallinity decrease from tachylite (a) to transitional (b) to sideromelane (c). Porosity and permeability data are from [32].

In addition to having a wide range of vesicle textures, lapilli also show large variability in groundmass crystallinity. Tabular plagioclase $+/-$ olivine characterize the macroscopic mineral assemblage of all clasts. Groundmass textures vary from nearly holocrystalline tachylite to hypocrystalline sideromelane, with many clasts having a transitional texture characterized by patches of both or an intermediate microlite abundance. We refer to three classes of groundmass in Table 2. Tachylite is a material characterized by tiny and closely spaced but not predominantly intergrown tiny microlites and nanolites, +/ glass, that, in aggregate, are optically opaque. This material may contain tiny domains of glass (sideromelane) or may be a mass of microlites and nanolites with effectively no remaining sideromelane.

Densely tachylitic clasts tend towards high vesicle number densities $\left(\mathrm{N}_{\mathrm{v}}\right)$, low porosity and low permeability (k), and those with sideromelane or low degrees of transitional groundmass crystallization tend to have lower $\mathrm{N}_{\mathrm{v}}$ but higher porosity and $\mathrm{k}$. Interactions between vesicles and microlites also differ through the lapilli population. In low-porosity tachylite clasts, vesicles are contorted and deformed, suggesting vesicle collapse accompanying extensive groundmass crystallization. In many clasts of transitional groundmass, vesicles are sub-spherical, and the patchy groundmass crystallinity appears to have overprinted a texture that had already developed by free bubble growth and coalescence in low-viscosity melt. 
Table 2. Textural parameters of lapilli from 3D micro-tomography.

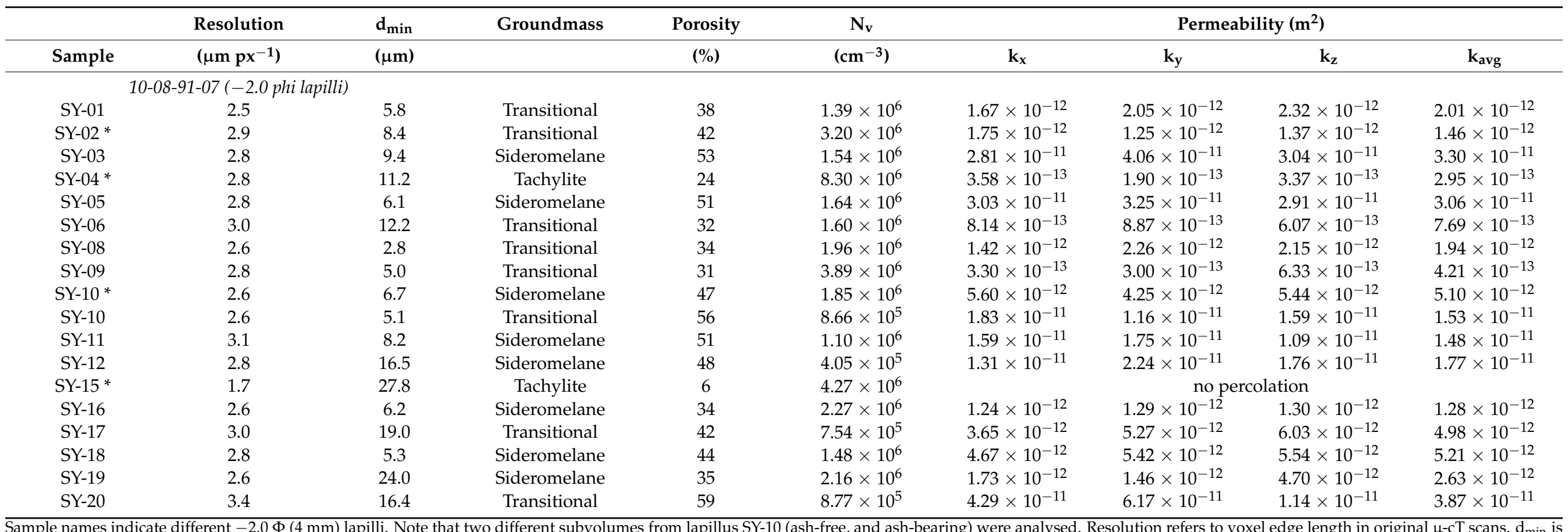

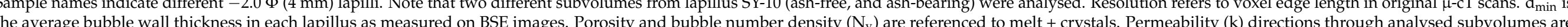
relative directions only, referenced to scan orientation. Note that porosity and permeability data are from [32].* indicates that vesicles in the analysed volume contain abundant ash. 


\section{Discussion}

Many previous studies on Surtseyan deposits have emphasized and interrogated the textures of blocky sideromelane ash fragments, the accepted characteristic and diagnostic particles of Surtseyan volcanism $[8,22,24,61-66]$, and more generally phreatomagmatic volcanism (e.g., [28,67-85]). We demonstrate and emphasize the generally overlooked variability of Surtseyan pyroclast textures, groundmass type, particle morphology, porosity and permeability for ash and lapilli. This variability reflects a diversity of processes active in Surtseyan volcanism.

\subsection{Pyroclast Groundmass}

Sideromelane glass is an abundant component (both for ash and lapilli) in Surtseyan pyroclasts, and more generally in basaltic phreatomagmatic deposits. However, sideromelane is also found in some dry eruptions ([86] and references therein). For example, it has been associated with intense lava fountaining at Kilauea, Hawaii, in 1959 [87], Strombolian (paroxysmal) and Hawaiian activity at Mount Etna [88], and Strombolian (normal) activity at Stromboli volcano [89]. Although produced in different contexts, in all cases, it results from rapid cooling that solidifies the melt before groundmass crystallization is significant. In the Surtseyan context, sideromelane is readily formed when magma is quenched during magma-water interaction $[8,9,62,90]$.

Tachylite is also common in both magmatic (e.g., $[88,89,91])$ and phreatomagmatic deposits (e.g., [52,55]), and it is generally considered to form when cooling conditions are slower than those forming sideromelane, allowing microlites to nucleate and grow within the groundmass. Tachylite has been inferred to form at different sites in basaltic eruptions, however, with only some directly associated with cooling rate. Prior to fragmentation, it forms through processes of mixing or mingling between magmas at different temperatures $[46,92]$, and by slower cooling and outgassing in the shallow conduit in proximity of the conduit walls, either as a result of parabolic velocity profile during magma ascent (e.g., [93]) or other conduit-margin complexities. In bombs, tachylitic interiors form by slower post-fragmentation cooling than the same bombs' sideromelane skins, and reheating of sideromelane during hot-state particle recycling/capture also produces tachylite.

While sideromelane is the predominant grain type in our ash and lapilli componentry analyses, especially in the ash fraction, tachylite and transitional groundmasses account for significant proportions of samples (Figure 3). This variation has also been reported from Surtseyan bombs and composite clasts, where many sideromelane pyroclasts contain captured particles that now have non-intergrown holocrystalline/tachylite groundmasses [36]. The cryptocrystalline tachylite portion of particles in Surtseyan pyroclasts, particularly in larger bombs and composite clasts, has been previously suggested to be due to crystallization by reheating and recycling during in-vent mixing of magma with a particle-water slurry [36], a fundamental aspect of Surtseyan volcanism [11,36]. However, the significant textural differences of tachylite compared to sideromelane and transitional clasts lead us to think that recycling derived from magma-slurry interactions may not be the only process responsible for tachylite clasts at Surtsey. For example, Murtagh and White [52] associated tachylitic textures of Surtseyan pyroclasts from Black Point, USA, to differential magma ascent rates in the shallow conduit, as hypothesized for some basaltic Plinian eruptions (e.g., [93]). Transitional clasts, however, present features more similar to sideromelane, including physical parameters such as porosity, bubble number density and permeability; intravent recycling is more likely to explain these textures (e.g., [94,95]).

A significant portion of non-sideromelane grains at Surtsey ( $17 \%$ for fine and coarse ash and $27 \%$ for lapilli-averaged across the samples investigated) and in general in Surtseyan deposits, highlights the complexity existing in Surtseyan eruptions. Such complexity provides opportunities to tease out additional information about eruption dynamics, both prior to and after magma fragmentation. 


\subsection{Pyroclast Porosity}

Surtseyan particles are typically described as containing spherical to elongate vesicles, which are small in comparison to vesicles in pyroclasts of dry eruptions $[8,13]$. High porosity is not commonly reported for particles produced by magma-water interactions [90], with broad and overall low ranges of particle porosity attributed to fragmentation and quenching at different depths and pressures, inferred to provide snapshots of exsolution states in a rising and decompressing magma [96], or the result of cross-conduit magma heterogeneity [52].

Our data reveal that clast porosity varies with groundmass type. The lapilli analysed for this study have porosity in the range 6-59\%, and permeability (k) from $2.95 \times 10^{-13}$ to $3.87 \times 10^{-11} \mathrm{~m}^{2}$ [32]. Combining this information with our bubble number densities, we observe that decreasing lapilli crystallinity (from tachylite, to transitional, to sideromelane) coincides with decreasing vesicle number density $\left(\mathrm{N}_{\mathrm{v}}\right)$ and increasing porosity and permeability (Figure 7, Table 2). Vesicles become increasingly more complex, contorted, and deformed with increasing crystallinity of the groundmass (Figure 7). In addition, in all but the dense outlier (SY-15 with porosity $6 \%$, Table 2), connected porosity makes up $>98 \%$ of the total. Similar results for lapilli porosity and bubble number density were obtained for Surtseyan pyroclasts of lacustrine eruptions [27].

While porosity is useful in providing information on conditions and rates of magma ascent [44] and has been inferred to distinguish magmatic from phreatomagmatic fragmentation, there are complications [86]. High porosity and high 2D bubble number densities are generally interpreted to characterize fragmentation in intense and dry, magmatic, eruptions [97]. High bubble number densities are also known, however, for Surtseyan pyroclasts from the lacustrine Black Point volcano, California, USA [52], where the highest $\mathrm{N}_{\mathrm{v}}$ is for a tachylite domain [52]. High porosity is reported from composite bombs containing variable domains and clasts of tachylite and sideromelane [36]. For Eldgja (Iceland) [91], Surtseyan phreatomagmatic pyroclasts extend to extreme vesicle number densities, counting $<10 \mu \mathrm{m}$ vesicles.

A known issue is that $2 \mathrm{D}+$ stereology results can differ strongly from $3 \mathrm{D}$ tomographic results for two reasons: stereology assumes spherical vesicles, and tomography may not resolve thin walls separating vesicles [98]. The result is that standard $2 \mathrm{D}+$ stereology vesicle characterization yields much higher $\mathrm{N}_{\mathrm{v}}$ values [99]. For example, when 3D microtomography (directly comparable with the tomography method used in [32]) was used to characterize vesicles for the same Black Point deposits, tomographically measured $N_{v}$ values are one to three orders of magnitude lower than those obtained from the $2 \mathrm{D}+$ stereology method [27]. Total porosity results are much less sensitive than $\mathrm{N}_{\mathrm{v}}$ values to choice of 2D + stereology or 3D methods. High porosity of Surtseyan bombs at Surtsey, analysed using 3D tomography [36], suggests post-fragmentation vesiculation, which is common for relatively large mafic particles due to the longer times before clasts cool and solidify $[45,100,101]$. A remaining challenge is that clasts with tachylite groundmasses seem, in general, to result in deviations from rise-rate-dominated interpretations of porosity patterns $[52,102,103]$ of mafic pyroclasts. That "deviation" is inferred to reflect magma outgassing that takes place at the same time as (or even drives) rapid crystallization of microlites and nanolites to produce tachylite groundmass.

The power-law relationship between permeability and porosity shown in Figure 8 is common in explosive volcanic products and has been linked to the application of percolation theory to pyroclast microstructures and magma fragmentation. Measurement of permeability and porosity in several samples (effusive and explosive) in order to investigate size and distribution of crystals and bubbles reveals a clear power-law relationship only for scoria samples [104] and none for analysed lavas. Similar results from a variety of products that differ in composition and texture [105,106], including natural and experimental products, indicate a link between bubble interconnectivity and magma fragmentation. Products of Plinian eruptions show the same relationships [107], but in a narrower range of porosity $(\phi=70-90 \%)$. 


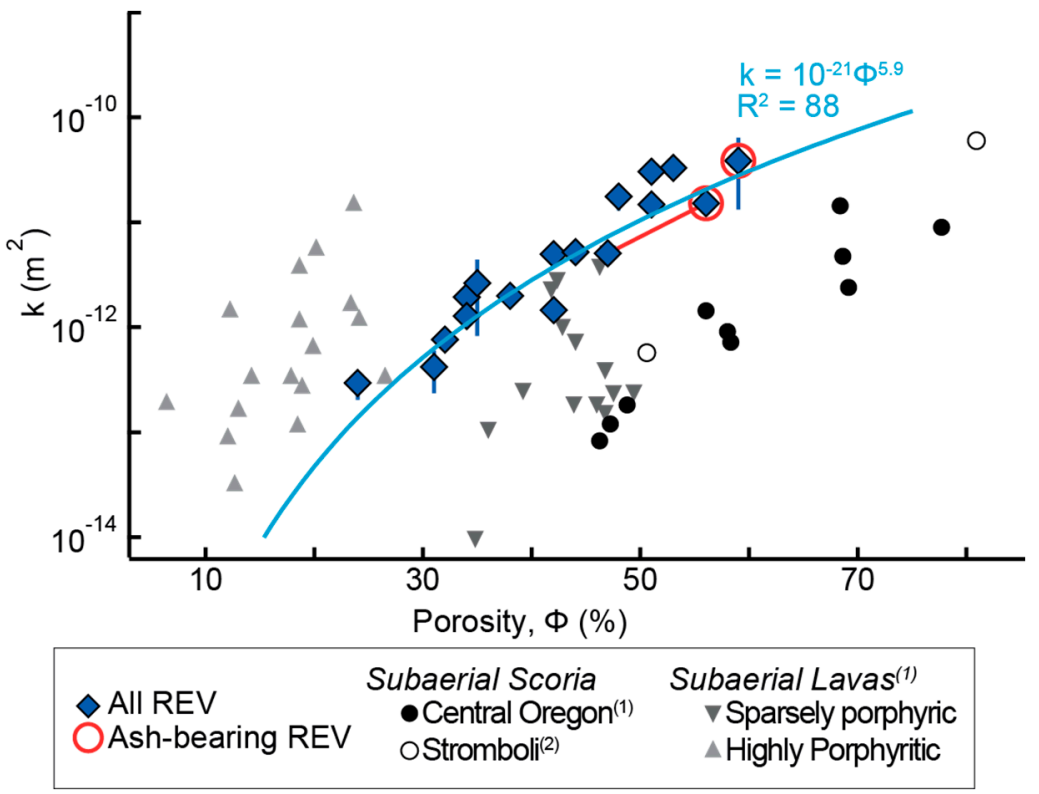

Figure 8. Permeability (k) versus porosity (in this figure, $\phi$ ). Blue diamonds are analysed subvolumes from [32] and used for this work. Ash-bearing subvolumes indicated by red circles. Red line connects the ash-free and ash-bearing subvolumes from within the same clast (SY-10; Table 1). Vertical error bars show maximum variability in $\mathrm{x}, \mathrm{y}$, and $\mathrm{z}$ directions, and are usually smaller than symbol size. Published data of subaerial scoria and basaltic lavas are shown for reference. ${ }^{1}[104],{ }^{2}[105,106]$.

If Surtseyan eruption styles are inferred based on characteristics of common sideromelane particles alone, then useful information may be missed because it resides in the wider range of vesicle microtextures preserved in tachylite and transitional groundmass types [52].

\subsection{Grain Shape}

Another particle characteristic noted to be diagnostic of Surtseyan activity has been the blocky morphology of grains in the ash fraction [8,22,24,61-66]. While blocky shapes, where clast-bounding fracture planes transect low to moderate proportions of largely noncontiguous vesicles, are prevalent in our study, other ash particle shapes are common. In Figures 4 and 6, for example, we see different morphologies, including blocky and vesicular ash particles as end members. Much variability in particle morphology reflects how vesicles intersect with a particle's surface and variations in the shapes, number density and size of bubbles [56]. From a quantitative perspective, 2D particle-shape characterization of particle cross-sections for different eruptive styles [56] reveals a wide range of shapes for ash particles at Surtsey. For the non-dimensional parameters of convexity and solidity, high ratios represent blocky particles, and lower ratios represent either glass shards or highly vesicular particles. Similar results, over an even wider spectrum, are known for another Surtseyan volcano, Black Point, California [27] in the western US, which again highlights the heterogeneity in morphology of Surtseyan ash particles.

Another group of ash grains in our sample collection are fluidal ones (Figure 6a-c). These grains result from magma fragmentation in a ductile regime and commonly represent the products of Hawaiian and Strombolian activity (e.g., [108]). They are found in other contexts, however, with Büttner [28], for example, showing that in experiments, these ductile particles (i.e., passive particles: Pele's hair and Pele's tears) form during the expansion phase of the MFCI (Molten Fuel Coolant Interaction). According to the same authors, blocky fine-ash particles (i.e., active particles) form prior to the expansion phase of the MFCI, in a brittle regime. We consider that magma-water interactions, in which MFCI and/or induced fuel-coolant interaction (IFCI) [109] plays a key role in fragmentation, is fundamental to Surtseyan eruptions, but it is not the only process active during fragmenta- 
tion. However, during Surtsey's eruption, the fluidal clasts examined here were produced by dry fountaining in August 1966.

The range of particle groundmass textures, morphology, and vesicle populations in Surtsey samples indicates that deposits are a mixture of active and "passive" phreatomagmatic particles, with some dry magmatic ones. We infer that most particles analysed were involved in and variably modified by particle ingestion and recycling within a watersaturated slurry $[36,57,86]$. Some clast shapes retain the signature of having been formed by magma-water interactions, but experimental work indicates that even in laboratory products, only $\sim 30 \%$ of particles record a signature from this fragmentation style [28]. Magma adjacent to an explosion can be fragmented without controlling or contributing to that explosion or expansion [86]. While these passive participants may not provide information about explosion mechanism, they contribute to the wide diversity of particle morphology that is ultimately preserved in the deposits of Surtseyan eruptions. Magma mingles more readily with a particle-water slurry compared to pure water, and at Surtsey, this slurry itself comprised tephra fallen or slumped into the vent, where magma then captured slurry particles during hot-state recycling before fragmenting to form composite bombs, lapilli and ash [36].

\subsection{Controls of Particle Diversity for Surtsey}

The observed range of textures within and variability among fragments is perhaps unsurprising, because Surtseyan eruptions exhibit a spectrum of behaviour that yields different signatures for each of the varied eruption styles. Pyroclast heterogeneity in dry basaltic eruptions is influenced primarily by exsolution (degassing) and outgassing of magma, upon which additional variation is imposed by waxing and waning eruption intensities, evolving conduit geometries, and modification of pyroclast textures during post-fragmentation cooling (e.g., [46-48,110]). Ash grains at Surtsey are typically poorly vesicular blocky to vesicular grains, with groundmasses of translucent sideromelane glass to optically opaque (cryptocrystalline) tachylite (e.g., [8,110]). Phreatomagmatic fragmentation involves the interaction of magma with external water in variable proportions [69] and styles of interaction; it adds another important element of heterogeneity. Rapid quenching of basaltic magma to sideromelane can preserve syn-fragmentation textures [45], but only a volumetrically small proportion of particles carry the morphological signature of direct magma-water interaction and fragmentation $[28,86]$.

Surtsey's eruption was highly heterogeneous because it encompassed both subaerial and subaqueous fragmentation, transport, cooling and deposition, with multiple vents active in different settings over a period of years. The shallow water to emergent setting of Surtsey commonly resulted in transitions from varied subaqueous processes to violent surface-observed phreatomagmatic explosions that energized both discrete "cypressoid" jets and those described as "continuous uprush". In contrast, weaker fire fountains are more typical of inferred similar subaerial basaltic eruptions dominated by magmatic fragmentation where external water is not significantly involved $[4,6,11,14]$. Fluctuations between dominantly phreatomagmatic and magmatic fragmentation styles continued as Surtsey's vents were periodically invaded by water and then again excluded, further enhancing heterogeneity of clasts produced through the eruption $[3,11,13]$.

A fundamental feature of Surtseyan volcanism, which also influences particle heterogeneity, is in-vent magma-slurry mingling $[11,13,36]$. A water-saturated slurry of ingested particles, deposited in the vent structure by fallback [14], cone-wall collapse [11,13,36], and unsuccessful ejection (e.g., [111]), readily mingles with magma, driving Surtseyan jets and columns characteristic of this eruption type [11,36]. The ingesting and recycling of clasts in the slurry modifies grain characteristics such as shape and groundmass crystallinity, and creates composite clasts [36] with each explosion, further diversifying fragments. 


\subsection{Deviant Particles? Implications of "Non-Standard" Particles from a Defining Eruption}

Volcanic eruptions are characteristically complex, and Surtseys' eruption was no exception. Volcanologists capture some of this eruptive complexity by naming styles based on examples, to which metrics are retrospectively attached, e.g., inferred column height and mass eruption rate for Plinian eruptions [112], or in Surtsey's case, high abundance of fines in near-vent deposits [9]. This two-step approach can create serious inconsistencies, as for example with Strombolian and Hawaiian eruptions [108]. In Surtsey's case, the defining characteristic extracted from the eruption was that magma-water interaction played a key role, and many eruptions quite different from that of Surtsey, such as maar-forming eruptions, have been classified as "Surtseyan" in influential studies, on the basis that magma-water interaction is inferred $[113,114]$. In turn, that inference commonly rests on the presence of weak to moderately vesicular sideromelane particles, while other particles are considered anomalous.

In documenting here a range of Surtsey's particle textures and focusing on what the non-characteristic ones reveal about the eruptive processes, we hope both to better represent this namesake eruption and to encourage consideration of particle microtextural and morphological diversity. Tachylite is not only an incidental component at Surtsey, but a key product of slurry recycling and reheating, as well as of conduit-margin stagnation as at Stromboli volcano itself and in Strombolian-style eruptions, whether subaerial or submarine [46,115]. If the products, particularly in the coarse ash/lapilli fraction of a Surtsey-like eruption, fully lack tachylite, then Surtsey's characteristic particle recycling and inferred conduit-wall outgassing may not be represented. Higher levels of tachylite could indicate a "very-Surtseyan" eruption with intense slurry recycling, or a less intense eruption with greater conduit-wall stagnation. Similar scenarios can be imagined for particle porosity or morphology, or abundance of composite clasts. These factors should be considered in characterizing Surtseyan eruptions.

\section{Conclusions}

Non-sideromelane pyroclasts are a characteristic minor but significant feature of Surtsey's deposits, both for ash and lapilli (17-27\%). However, Surtseyan deposits have often been interpreted as such solely based on the presence of blocky sideromelane ash fragments, such that the variability of porosity, particle morphology and crystallinity in function of grain size has not been well explored. Morphology of grains can be controlled by groundmass crystallinity and porosity. Porosity has in turn been demonstrated in our study to vary with groundmass crystallinity-simpler textures are preserved in sideromelane, and more-complex vesicle shapes and the highest bubble number densities are found in tachylite and transitional fragments. Constricting focus to the more prevalent and characteristic grain-type for Surtseyan products neglects this diversity of particles and obscures from view the wider diversity of pyroclasts created by Surtseyan eruptions, and the processes that produce them.

Author Contributions: Original draft preparation, A.V.; conceptualization, J.D.L.W. and C.I.S.; field sampling, T.T., J.D.L.W. and C.I.S.; writing-review and editing, A.V., J.D.L.W., R.J.M.B., C.I.S. and T.T.; acquisition of 3D micro-tomography data, 2D porosity data, BSE and SEM images, C.I.S.; grain size and componentry analysis, R.J.M.B.; acquisition of microscopic optical images, A.V. All authors have read and agreed to the published version of the manuscript.

Funding: This research was supported by a University of Otago Publishing Bursary (A.V.), University of Otago Research Grant Funds and subcontracts from GNS Science (J.D.L.W. and R.J.M.B.), Otago Summer student scholarship (R.J.M.B.) and a Postdoctoral Fellowship from l'Université d'Orléans (C.I.S.).

Data Availability Statement: Not applicable. 
Acknowledgments: The authors would like to thank the editor and the two anonymous reviewers for their efforts in reviewing this manuscript.

Conflicts of Interest: The authors declare no conflict of interest.

\section{References}

1. Jakobsson, S.P.; Moore, J.G. The Surtsey Research Drilling Project of 1979. Surtsey Res. Progress Rep. 1982, 9, 76-93.

2. Thorarinsson, S. Sitt Af Hverju Um Surtseyjargosið [Surtsey]. Natturufroeingurinn 1996, 35, 153-212.

3. Thorarinsson, S. Surtsey, the New Island in the North Atlantic. Reykjavik: Almenna Bokofelagid; Viking Press: New York, NY, USA, 1967.

4. Thorarinsson, S.; Einarsson, T.; Sigvaldason, G.; Elisson, G. The Submarine Eruption off the Vestmann Islands 1963-64: A Preliminary Report. Bull. Volcanol. 1964, 27, 435-445. [CrossRef]

5. Thorarinsson, S. Submarine Eruptions around Iceland. Náttúrufræðingurinn 1965, 35, 49-74.

6. Thorarinsson, S. The Surtsey Eruption and Related Scientific Work. Polar Rec. 1967, 13, 571. [CrossRef]

7. Tazieff, H. Sur le mécanisme des éruptions basaltiques sous-marines à faibles profundeurs et la genèse d'hyaloclastites associées. Geol. Rundsch 1968, 57, 955-966. [CrossRef]

8. Walker, G.P.L.; Croasdale, R. Characteristics of Some Basaltic Pyroclastics. Bull. Volcanol. 1971, 35, 303-317. [CrossRef]

9. Walker, G.P.L. Explosive Volcanic Eruptions-A New Classification Scheme. Geol. Rundsch. 1973, 62, 431-446. [CrossRef]

10. Lorenz, V. Vesiculated Tuffs and Related Features. Sedimentology 1974, 21, 273-291. [CrossRef]

11. Kokelaar, B.P. The Mechanism of Surtseyan Volcanism. J. Geol. Soc. 1983, 140, 939-944. [CrossRef]

12. Kokelaar, B.P.; Durant, G.P. The Submarine Eruption and Erosion of Surtla (Surtsey), Iceland. J. Volcanol. Geotherm. Res. 1983, 19, 239-246. [CrossRef]

13. Moore, J.G. Structure and Eruptive Mechanisms at Surtsey Volcano, Iceland. Geol. Mag. 1985, 122, 649. [CrossRef]

14. White, J.D.L. Pre-Emergent Construction of a Lacustrine Basaltic Volcano, Pahvant Butte, Utah (USA). Bull. Volcanol. 1996, 58, 249-262. [CrossRef]

15. White, J.D.L.; Houghton, B.F. Surtseyan and Related Phreatomagmatic Eruptions. In Encyclopedia of Volcanoes; Academic Press: Cambridge, MA, USA, 2000; pp. 495-511.

16. Thordarson, T. Physical Volcanology of Surtsey, Iceland: A Preliminary Report. Surtsey Res. 2000, 11, 109-126. Available online: Https:/ /Surtsey.Is/Wp-Content/Uploads/2019/08/2000_XII_4_02.Pdf (accessed on 28 January 2022).

17. Thordarson, T. Studies in Volcanology: The Legacy of George Walker; Geological Society of London: London, UK, 2009; ISBN 978-1-86239-280-9.

18. Schipper, C.I.; Jakobsson, S.P.; White, J.D.L.; Palin, J.M.; Bush-Marcinowski, T. The Surtsey Magma Series. Sci. Rep. 2015, 5, 11498. [CrossRef] [PubMed]

19. Thordarson, T.; Sigmarsson, O. Effusive Activity in the 1963-1967 Surtsey Eruption, Iceland: Flow Emplacement and Growth of Small Lava Shields. Studies in Volcanology: The Legacy of George Walker. Spec. Pub. IAVCEI 2009, 2, 53-84.

20. Machado, F.; Parsons, W.H.; Richards, A.F.; Mulford, J.W. Capelinhos Eruption of Fayal Volcano, Azores, 1957-1958. J. Geophys. Res. 1962, 67, 3519-3529. [CrossRef]

21. Waters, A.C.; Fisher, R.V. Base Surges and Their Deposits: Capelinhos and Taal Volcanoes. J. Geophys. Res. 1971, 76, 5596-5614. [CrossRef]

22. Cole, P.D.; Guest, J.E.; Duncan, A.M.; Pacheco, J.-M. Capelinhos 1957-1958, Faial, Azores: Deposits Formed by an Emergent Surtseyan Eruption. Bull. Volcanol. 2001, 63, 204-220. [CrossRef]

23. Baker, E.T.; Massoth, G.J. Observations and Sampling of an Ongoing Subsurface Eruption of Kavachi Volcano, Solomon Islands, May 2000. Geology 2002, 30, 975-978. [CrossRef]

24. Sorrentino, L.; Cas, R.A.F.; Stilwell, J.D. Evolution and Facies Architecture of Paleogene Surtseyan Volcanoes on Chatham Islands, New Zealand, Southwest Pacific Ocean. J. Volcanol. Geotherm. Res. 2011, 202, 1-21. [CrossRef]

25. Moorhouse, B.L.; White, J.D.L.; Scott, J.M. Cape Wanbrow: A Stack of Surtseyan-Style Volcanoes Built over Millions of Years in the Waiareka-Deborah Volcanic Field, New Zealand. J. Volcanol. Geotherm. Res. 2015, 298, 27-46. [CrossRef]

26. Verolino, A.; White, J.D.L.; Brenna, M. Eruption Dynamics at Pahvant Butte Volcano, Utah, Western USA: Insights from Ash-Sheet Dispersal, Grain Size, and Geochemical Data. Bull. Volcanol. 2018, 80, 81. [CrossRef]

27. Verolino, A.; White, J.D.L.; Dürig, T.; Cappuccio, F. Black Point-Pyroclasts of a Surtseyan Eruption Show No Change during Edifice Growth to the Surface from 100 m Water Depth. J. Volcanol. Geotherm. Res. 2019, 384, 85-102. [CrossRef]

28. Büttner, R.; Dellino, P.; La Volpe, L.; Lorenz, V.; Zimanowski, B. Thermohydraulic Explosions in Phreatomagmatic Eruptions as Evidenced by the Comparison between Pyroclasts and Products from Molten Fuel Coolant Interaction Experiments: THERMOHYDRAULIC EXPLOSIONS. J. Geophys. Res. 2002, 107, ECV 5-1-ECV 5-14. [CrossRef]

29. Cantelli, A.; Johnson, S.; White, J.; Parker, G. Sediment Sorting in the Deposits of Turbidity Currents Created by Experimental Modeling of Explosive Subaqueous Eruptions. J. Geol. 2008, 116, 76-93. [CrossRef]

30. McGuinness, M.J.; Greenbank, E.; Schipper, C.I. Modelling Vapour Transport in Surtseyan Bombs. J. Volcanol. Geotherm. Res. 2016, 318, 103-113. [CrossRef] 
31. Verolino, A.; White, J.D.L.; Zimanowski, B. Particle Transport in Subaqueous Eruptions: An Experimental Investigation. J. Volcanol. Geotherm. Res. 2017, 349, 298-310. [CrossRef]

32. Greenbank, E.; McGuinness, M.J.; Schipper, C.I. A Theoretical Model of Surtseyan Bomb Fragmentation. Proc. R. Soc. A 2021, 477, 20210166. [CrossRef]

33. Schipper, C.I.; Le Voyer, M.; Moussallam, Y.; White, J.D.L.; Thordarson, T.; Kimura, J.-I.; Chang, Q. Degassing and Magma Mixing during the Eruption of Surtsey Volcano (Iceland, 1963-1967): The Signatures of a Dynamic and Discrete Rift Propagation Event. Bull. Volcanol. 2016, 78, 33. [CrossRef]

34. Schipper, C.I.; Moussallam, Y. Temporal Redox Variation in Basaltic Tephra from Surtsey Volcano (Iceland). Bull. Volcanol. 2017, 79, 71. [CrossRef]

35. Romagnoli, C.; Jakobsson, S.P. Post-Eruptive Morphological Evolution of Island Volcanoes: Surtsey as a Modern Case Study. Geomorphology 2015, 250, 384-396. [CrossRef]

36. Schipper, C.I.; White, J.D.L. Magma-Slurry Interaction in Surtseyan Eruptions. Geology 2016, 44, 195-198. [CrossRef]

37. Sayyadi, S.; Einarsson, P.; Gudmundsson, M.T. Seismic Activity Associated with the 1963-1967 Surtsey Eruption off the Coast of South Iceland. Bull. Volcanol. 2021, 83, 54. [CrossRef]

38. Jackson, M.D.; Couper, S.; Stan, C.V.; Ivarsson, M.; Czabaj, M.W.; Tamura, N.; Parkinson, D.; Miyagi, L.M.; Moore, J.G. Authigenic Mineral Texture in Submarine 1979 Basalt Drill Core, Surtsey Volcano, Iceland. Geochem. Geophys. Geosyst. 2019, 20, 3751-3773. [CrossRef]

39. Kleine, B.I.; Stefánsson, A.; Kjartansdóttir, R.; Prause, S.; Weisenberger, T.B.; Reynolds, H.I.; Sveinbjörnsdóttir, Á.E.; Jackson, M.D.; Gudmundsson, M.T. The Surtsey Volcano Geothermal System: An Analogue for Seawater-Oceanic Crust Interaction with Implications for the Elemental Budget of the Oceanic Crust. Chem. Geol. 2020, 550, 119702. [CrossRef]

40. Prause, S.; Weisenberger, T.B.; Cappelletti, P.; Grimaldi, C.; Rispoli, C.; Jónasson, K.; Jackson, M.D.; Gudmundsson, M.T. Alteration Progress within the Surtsey Hydrothermal System, SW Iceland-A Time-Lapse Petrographic Study of Cores Drilled in 1979 and 2017. J. Volcanol. Geotherm. Res. 2020, 392, 106754. [CrossRef]

41. Cashman, K.; Scheu, B. Magmatic Fragmentation. In The Encyclopedia of Volcanoes; Sigurdsson, H., Houghton, B.F., Rymer, H., Stix, J., McNutt, S., Eds.; Academic Press: New York, NY, USA, 2015; pp. 464-470.

42. Zimanowski, B.; Büttner, R.; Dellino, P.; White, J.D.L.; Wohletz, K.H. Water-Magma Interaction and Phreatomagmatic Fragmentation. In The Encyclopedia of Volcanoes; Sigurdsson, H., Houghton, B.F., Rymer, H., Stix, J., McNutt, S., Eds.; Academic Press: New York, NY, USA, 2015; pp. 473-484.

43. Cashman, K.V.; Mangan, M.T. Physical Aspects of Magmatic Degassing II. Constraints on Vesiculation Processes Form Textural Studies of Eruptive Products; Carroll, M.R., Ed.; Volatiles in Magmas, Mineralogical Society of America: Chantilly, VA, USA, 1994; pp. 447-478.

44. Shea, T.; Houghton, B.F.; Gurioli, L.; Cashman, K.V.; Hammer, J.E.; Hobden, B.J. Textural Studies of Vesicles in Volcanic Rocks: An Integrated Methodology. J. Volcanol. Geotherm. Res. 2010, 190, 271-289. [CrossRef]

45. Schipper, C.I.; White, J.D.L.; Houghton, B.F. Syn- and Post-Fragmentation Textures in Submarine Pyroclasts from Lō'ihi Seamount, Hawai'i. J. Volcanol. Geotherm. Res. 2010, 191, 93-106. [CrossRef]

46. Lautze, N.C.; Houghton, B.F. Physical Mingling of Magma and Complex Eruption Dynamics in the Shallow Conduit at Stromboli Volcano, Italy. Geology 2005, 33, 425. [CrossRef]

47. Sable, J.E.; Houghton, B.F.; Wilson, C.J.N.; Carey, R.J. Eruption Mechanisms during the Climax of the Tarawera 1886 Basaltic Plinian Eruption Inferred from Microtextural Characteristics of the Deposits. In Studies in Volcanology: The Legacy of George Walker; Special Publications of IAVCEI; The Geological Society Of London: London, UK, 2009; Volume 2, pp. $129-154$.

48. Stovall, W.K.; Houghton, B.F.; Gonnermann, H.; Fagents, S.A.; Swanson, D.A. Eruption Dynamics of Hawaiian-Style Fountains: The Case Study of Episode 1 of the Kīlauea Iki 1959 Eruption. Bull. Volcanol. 2011, 73, 511-529. [CrossRef]

49. McPhie, J.; White, J.D.L.; Gorny, C.; Jackson, M.D.; Gudmundsson, M.T.; Couper, S. Lithofacies from the 1963-1967 Surtsey Eruption in SUSTAIN Drill Cores SE-2a, SE-2b and SE-03. Surtsey Res. 2020, 14, 19-32. [CrossRef]

50. Moore, J.G.; Jackson, M.D. Observations on the Structure of Surtsey. Surtsey Res. 2020, 14, 33-45. [CrossRef]

51. Kokelaar, P. Magma-Water Interactions in Subaqueous and Emergent Basaltic. Bull. Volcanol. 1986, 48, 275-289. [CrossRef]

52. Murtagh, R.M.; White, J.D.L. Pyroclast Characteristics of a Subaqueous to Emergent Surtseyan Eruption, Black Point Volcano, California. J. Volcanol. Geotherm. Res. 2013, 267, 75-91. [CrossRef]

53. Shimano, T.; Nakada, S. Vesiculation Path of Ascending Magma in the 1983 and the 2000 Eruptions of Miyakejima Volcano, Japan. Bull. Volcanol. 2006, 68, 549-566. [CrossRef]

54. Mattsson, H.B. Textural Variation in Juvenile Pyroclasts from an Emergent, Surtseyan-Type, Volcanic Eruption: The Capelas Tuff Cone, São Miguel (Azores). J. Volcanol. Geotherm. Res. 2010, 189, 81-91. [CrossRef]

55. Murtagh, R.M.; White, J.D.L.; Sohn, Y.K. Pyroclast Textures of the Ilchulbong 'Wet' Tuff Cone, Jeju Island, South Korea. J. Volcanol. Geotherm. Res. 2011, 201, 385-396. [CrossRef]

56. Liu, E.J.; Cashman, K.V.; Rust, A.C. Optimising Shape Analysis to Quantify Volcanic Ash Morphology. GeoResJ 2015, 8, 14-30. [CrossRef]

57. White, J.D.L.; Houghton, B.F. Primary Volcaniclastic Rocks. Geology 2006, 34, 677. [CrossRef]

58. Blott, S.J.; Pye, K. GRADISTAT: A Grain Size Distribution and Statistics Package for the Analysis of Unconsolidated Sediments. Earth Surf. Processes Landf. 2001, 26, 1237-1248. [CrossRef] 
59. Deardorff, N.; Cashman, K. Rapid Crystallization during Recycling of Basaltic Andesite Tephra: Timescales Determined by Reheating Experiments. Sci. Rep. 2017, 7, 46364. [CrossRef]

60. Büttner, R.; Dellino, P.; Zimanowski, B. Identifying Magma-Water Interaction from the Surface Features of Ash Particles. Nature 1999, 401, 688-690. [CrossRef]

61. Heiken, G. Morphology and Petrography of Volcanic Ashes. GSA Bull. 1972, 83, 1961-1988. [CrossRef]

62. Heiken, G. Atlas of Volcanic Ash. Smithson. Contrib. Earth Sci. 1974, 1-101. [CrossRef]

63. Wohletz, K.H. Mechanisms of Hydrovolcanic Pyroclast Formation: Grain-Size, Scanning Electron Microscopy, and Experimental Studies. J. Volcanol. Geotherm. Res. 1983, 17, 31-63. [CrossRef]

64. Kano, K. A Shallow-Marine Alkali-Basalt Tuff Cone in the Middle Miocene Jinzai Formation, Izumo, SW Japan. J. Volcanol. Geotherm. Res. 1998, 87, 173-191. [CrossRef]

65. White, R.V.; Castillo, P.R.; Neal, C.R.; Fitton, J.G.; Godard, M. Phreatomagmatic Eruptions on the Ontong Java Plateau: Chemical and Isotopic Relationship to Ontong Java Plateau Basalts. Geol. Soc. Lond. Spec. Publ. 2004, 229, 307-323. [CrossRef]

66. Graettinger, A.H.; Skilling, I.; McGarvie, D.; Höskuldsson, Á. Subaqueous Basaltic Magmatic Explosions Trigger Phreatomagmatism: A Case Study from Askja, Iceland. J. Volcanol. Geotherm. Res. 2013, 264, 17-35. [CrossRef]

67. Self, S. Large-Scale Phreatomagmatic Silicic Volcanism: A Case Study from New Zealand. J. Volcanol. Geotherm. Res. 1983, 17, 433-469. [CrossRef]

68. Houghton, B.F.; Hackett, W.R. Strombolian and Phreatomagmatic Deposits of Ohakune Craters, Ruapehu, New Zealand: A Complex Interaction between External Water and Rising Basaltic Magma. J. Volcanol. Geotherm. Res. 1984, 21, 207-231. [CrossRef]

69. Wohletz, K.H. Explosive Magma-Water Interactions: Thermodynamics, Explosion Mechanisms, and Field Studies. Bull. Volcanol. 1986, 48, 245-264. [CrossRef]

70. Cioni, R.; Sbrana, A.; Vecci, R. Morphologic Features of Juvenile Pyroclasts from Magmatic and Phreatomagmatic Deposits of Vesuvius. J. Volcanol. Geotherm. Res. 1992, 51, 61-78. [CrossRef]

71. Zimanowski, B.; Büttner, R.; Lorenz, V.; Häfele, H.-G. Fragmentation of Basaltic Melt in the Course of Explosive Volcanism. J. Geophys. Res. Solid Earth 1997, 102, 803-814. [CrossRef]

72. De Rita, D.; Giordano, G.; Esposito, A.; Fabbri, M.; Rodani, S. Large Volume Phreatomagmatic Ignimbrites from the Colli Albani Volcano (Middle Pleistocene, Italy). J. Volcanol. Geotherm. Res. 2002, 118, 77-98. [CrossRef]

73. Martin, U.; Németh, K.; Auer, A.; Breitkreuz, C.; Freiberg, T.B. Mio-Pliocene Phreatomagmatic Volcanism in a Fluvio-Lacustrine Basin in Western Hungary. Geolines 2003, 15, 84-90.

74. Porreca, M.; Giordano, G.; Mattei, M.; Musacchio, P. Evidence of Two Holocene Phreatomagmatic Eruptions at Stromboli Volcano (Aeolian Islands) from Paleomagnetic Data. Geophys. Res. Lett. 2006, 33, L21316. [CrossRef]

75. Németh, K.; Martin, U. Shallow Sill and Dyke Complex in Western Hungary as a Possible Feeding System of Phreatomagmatic Volcanoes in "Soft-Rock" Environment. J. Volcanol. Geotherm. Res. 2007, 159, 138-152. [CrossRef]

76. Austin-Erickson, A.; Büttner, R.; Dellino, P.; Ort, M.H.; Zimanowski, B. Phreatomagmatic Explosions of Rhyolitic Magma: Experimental and Field Evidence. J. Geophys. Res. 2008, 113, B11201. [CrossRef]

77. Geshi, N.; Oikawa, T. Phreatomagmatic Eruptions Associated with the Caldera Collapse during the Miyakejima 2000 Eruption, Japan. J. Volcanol. Geotherm. Res. 2008, 176, 457-468. [CrossRef]

78. Wong, L.J.; Larsen, J.F. The Middle Scoria Sequence: A Holocene Violent Strombolian, Subplinian and Phreatomagmatic Eruption of Okmok Volcano, Alaska. Bull. Volcanol. 2009, 72, 17. [CrossRef]

79. Németh, K. Volcanic Glass Textures, Shape Characteristics and Compositions of Phreatomagmatic Rock Units from the Western Hungarian Monogenetic Volcanic Fields and Their Implications for Magma Fragmentation. Open Geosci. 2010, 2, 399-419. [CrossRef]

80. Martí, J.; Planagumà, L.; Geyer, A.; Canal, E.; Pedrazzi, D. Complex Interaction between Strombolian and Phreatomagmatic Eruptions in the Quaternary Monogenetic Volcanism of the Catalan Volcanic Zone (NE of Spain). J. Volcanol. Geotherm. Res. 2011, 201, 178-193. [CrossRef]

81. Van Otterloo, J.; Cas, R.A.F.; Sheard, M.J. Eruption Processes and Deposit Characteristics at the Monogenetic Mt. Gambier Volcanic Complex, SE Australia: Implications for Alternating Magmatic and Phreatomagmatic Activity. Bull. Volcanol. 2013, 75, 737. [CrossRef]

82. Tarff, R.W.; Day, S.J. Chilled Margin Fragmentation as a Trigger for Transition from Strombolian to Phreatomagmatic Explosive Activity at Cova de Paul Crater, Santo Antao, Cape Verde Islands. Bull. Volcanol. 2013, 75, 735. [CrossRef]

83. Iverson, N.A.; Lieb-Lappen, R.; Dunbar, N.W.; Obbard, R.; Kim, E.; Golden, E. The First Physical Evidence of Subglacial Volcanism under the West Antarctic Ice Sheet. Sci. Rep. 2017, 7, 11457. [CrossRef] [PubMed]

84. Alvarado, G.E.; Mele, D.; Dellino, P.; de Moor, J.M.; Avard, G. Are the Ashes from the Latest Eruptions (2010-2016) at Turrialba Volcano (Costa Rica) Related to Phreatic or Phreatomagmatic Events? J. Volcanol. Geotherm. Res. 2016, 327, 407-415. [CrossRef]

85. Aydar, E.; ÇİNer, A.; Ersoy, O.; ÉCochard, E.; Fouache, E.G. Volcanic Ash and Tsunami Record of the Minoan Late Bronze Age Eruption (Santorini) in a Distal Setting, Southwestern Turkey. J. Quat. Sci. 2021, 36, 586-597. [CrossRef]

86. White, J.D.L.; Valentine, G.A. Magmatic versus Phreatomagmatic Fragmentation: Absence of Evidence Is Not Evidence of Absence. Geosphere 2016, 12, 1478-1488. [CrossRef]

87. Stovall, W.K.; Houghton, B.F.; Hammer, J.E.; Fagents, S.A.; Swanson, D.A. Vesiculation of High Fountaining Hawaiian Eruptions: Episodes 15 and 16 of 1959 Kìlauea Iki. Bull. Volcanol. 2012, 74, 441-455. [CrossRef] 
88. Polacci, M.; Corsaro, R.; Andronico, D. Coupled Textural and Compositional Characterization of Basaltic Scoria: Insights into the Transition from Strombolian to Fire Fountain Activity at Mount Etna, Italy. Geology 2006, 34, 201. [CrossRef]

89. Lautze, N.; Taddeucci, J.; Andronico, D.; Houghton, B.; Niemeijer, A.; Scarlato, P. Insights into Explosion Dynamics and the Production of Ash at Stromboli from Samples Collected in Real-Time, October 2009. In Geological Society of America Special Papers; Geological Society of America: Boulder, CO, USA, 2013; Volume 498, pp. 125-139, ISBN 978-0-8137-2498-0.

90. Fisher, R.V.; Schmincke, H.U. Pyroclastic Rocks; Springer: Berlin, Germany, 1984; p. 472.

91. Moreland, W.M.; Thordarson, T.; Houghton, B.F.; Larsen, G. Driving Mechanisms of Subaerial and Subglacial Explosive Episodes during the 10th Century Eldgjá Fissure Eruption, Southern Iceland. Volcanica 2019, 2, 129-150. [CrossRef]

92. Cimarelli, C.; Di Traglia, F.; Taddeucci, J. Basaltic Scoria Textures from a Zoned Conduit as Precursors to Violent Strombolian Activity. Geology 2010, 38, 439-442. [CrossRef]

93. Costantini, L.; Houghton, B.F.; Bonadonna, C. Constraints on Eruption Dynamics of Basaltic Explosive Activity Derived from Chemical and Microtextural Study: The Example of the Fontana Lapilli Plinian Eruption, Nicaragua. J. Volcanol. Geotherm. Res. 2010, 189, 207-224. [CrossRef]

94. D'Oriano, C.; Bertagnini, A.; Cioni, R.; Pompilio, M. Identifying Recycled Ash in Basaltic Eruptions. Sci. Rep. 2015, 4, 5851. [CrossRef] [PubMed]

95. Hantusch, M.; Lacanna, G.; Ripepe, M.; Montenegro, V.; Valderrama, O.; Farias, C.; Caselli, A.; Gabellini, P.; Cioni, R. Low-Energy Fragmentation Dynamics at Copahue Volcano (Argentina) as Revealed by an Infrasonic Array and Ash Characteristics. Front. Earth Sci. 2021, 9, 92. [CrossRef]

96. Houghton, B.F.; Wilson, C.J.N. A Vesicularity Index for Pyroclastic Deposits. Bull. Volcanol. 1989, 51, 451-462. [CrossRef]

97. Polacci, M.; Mancini, L.; Baker, D.R. The Contribution of Synchrotron X-Ray Computed Microtomography to Understanding Volcanic Processes. J. Synchrotron Rad. 2010, 17, 215-221. [CrossRef] [PubMed]

98. Giachetti, T.; Burgisser, A.; Arbaret, L.; Druitt, T.H.; Kelfoun, K. Quantitative Textural Analysis of Vulcanian Pyroclasts (Montserrat) Using Multi-Scale X-Ray Computed Microtomography: Comparison with Results from 2D Image Analysis. Bull. Volcanol. 2011, 73, 1295-1309. [CrossRef]

99. Verolino, A. Surtseyan Volcanism: Case Studies from Pahvant Butte and Black Point. Ph.D. Thesis, University of Otago, Dunedin, New Zealand, 2019.

100. Rust, A.C.; Cashman, K.V. Permeability Controls on Expansion and Size Distributions of Pyroclasts. J. Geophys. Res. Solid Earth 2011, 116. [CrossRef]

101. Browning, J.; Tuffen, H.; James, M.R.; Owen, J.; Castro, J.M.; Halliwell, S.; Wehbe, K. Post-Fragmentation Vesiculation Timescales in Hydrous Rhyolitic Bombs from Chaitén Volcano. J. South Am. Earth Sci. 2020, 104, 102807. [CrossRef]

102. Taddeucci, J.; Pompilio, M.; Scarlato, P. Conduit Processes during the July-August 2001 Explosive Activity of Mt. Etna (Italy): Inferences from Glass Chemistry and Crystal Size Distribution of Ash Particles. J. Volcanol. Geotherm. Res. 2004, 137, 33-54. [CrossRef]

103. Bae, S.-G.; Choo, C.-O.; Jang, Y.-D. Mineralogical Characteristics of Tachylite occurring in Basic Dike, Basaltic Agglomerate Formation, Ulleung Island and Its Implications of Volcanic Activity. J. Mineral. Soc. Korea 2012, 25, 63-76. [CrossRef]

104. Saar, M.O.; Manga, M. Permeability-Porosity Relationship in Vesicular Basalts. Geophys. Res. Lett. 1999, 26, 111-114. [CrossRef]

105. Mueller, S.; Melnik, O.; Spieler, O.; Scheu, B.; Dingwell, D.B. Permeability and Degassing of Dome Lavas Undergoing Rapid Decompression: An Experimental Determination. Bull. Volcanol. 2005, 67, 526-538. [CrossRef]

106. Mueller, S.; Scheu, B.; Spieler, O.; Dingwell, D.B. Permeability Control on Magma Fragmentation. Geology 2008, 36, 399. [CrossRef]

107. Gonnermann, H.M.; Giachetti, T.; Fliedner, C.; Nguyen, C.T.; Houghton, B.F.; Crozier, J.A.; Carey, R.J. Permeability During Magma Expansion and Compaction. J. Geophys. Res. Solid Earth 2017, 122, 9825-9848. [CrossRef]

108. Taddeucci, J.; Edmonds, M.; Houghton, B.F.; James, M.R.; Vergniolle, S. Hawaiian and Strombolian Eruptions. In The Encyclopedia of Volcanoes; Sigurdsson, H., Houghton, B.F., Rymer, H., Stix, J., McNutt, S., Eds.; Academic Press: New York, NY, USA, 2015; pp. 485-499.

109. Dürig, T.; White, J.D.L.; Murch, A.P.; Zimanowski, B.; Büttner, R.; Mele, D.; Dellino, P.; Carey, R.J.; Schmidt, L.S.; Spitznagel, N. Deep-sea eruptions boosted by induced fuel-coolant explosions. Nat. Geosci. 2020, 13, 498-503. [CrossRef]

110. Houghton, B.F.; Gonnermann, H.M. Basaltic Explosive Volcanism: Constraints from Deposits and Models. Geochemistry 2008, 68, 117-140. [CrossRef]

111. White, J.D.L.; Ross, P.-S. Maar-Diatreme Volcanoes: A Review. J. Volcanol. Geotherm. Res. 2011, 201, 1-29. [CrossRef]

112. Bonadonna, C.; Costa, A. Plume Height, Volume, and Classification of Explosive Volcanic Eruptions Based on the Weibull Function. Bull. Volcanol. 2013, 75, 742. [CrossRef]

113. Wohletz, K.H.; Sheridan, M.F. Hydrovolcanic Explosions; II, Evolution of Basaltic Tuff Rings and Tuff Cones. Am. J. Sci. 1983, 283, 385-413. [CrossRef]

114. Wohletz, K.H.; McQueen, R.G. Experimental Studies of Hydromagmatic Volcanism. In Inception, Evolution, and Hazards; Panel on Explosive Volcanism; National Academy Press: Washington, DC, USA, 1984; pp. 158-169.

115. Schipper, C.I.; White, J.D.L.; Houghton, B.F. Textural, Geochemical, and Volatile Evidence for a Strombolian-like Eruption Sequence at Lōihi Seamount, Hawaii. J. Volcanol. Geotherm. Res. 2011, 207, 16-32. [CrossRef] 